\title{
Ruggedness: The Blessing of Bad Geography in Africa
}

\section{Citation}

Nunn, Nathan, and Diego Puga. 2012. "Ruggedness: The Blessing of Bad Geography in Africa." Review of Economics and Statistics 94 (1) (February): 20-36. doi:10.1162/rest_a_00161.

\section{Published Version}

10.1162/REST_a_00161

\section{Permanent link}

http://nrs.harvard.edu/urn-3:HUL.InstRepos:29412035

\section{Terms of Use}

This article was downloaded from Harvard University's DASH repository, and is made available under the terms and conditions applicable to Other Posted Material, as set forth at http:// nrs.harvard.edu/urn-3:HUL.InstRepos:dash.current.terms-of-use\#LAA

\section{Share Your Story}

The Harvard community has made this article openly available.

Please share how this access benefits you. Submit a story.

Accessibility 


\title{
RUGGEDNESS: THE BLESSING OF BAD GEOGRAPHY IN AFRICA
}

\author{
Nathan Nunn and Diego Puga*
}

Abstract-We show that geography, through its impact on history, can have important effects on economic development today. The analysis focuses on the historic interaction between ruggedness and Africa's slave trades. Although rugged terrain hinders trade and most productive activities, negatively affecting income globally, rugged terrain within Africa afforded protection to those being raided during the slave trades. Since the slave trades retarded subsequent economic development, ruggedness within Africa has also had a historic indirect positive effect on income. Studying all countries worldwide, we estimate the differential effect of ruggedness on income for Africa. We show that the differential effect of ruggedness is statistically significant and economically meaningful, it is found in Africa only, it cannot be explained by other factors like Africa's unique geographic environment, and it is fully accounted for by the history of the slave trades.

\section{Introduction}

$\mathrm{R}$ UGGED terrain is tough to farm, costly to traverse, and often inhospitable to live in; yet in Africa, countries with a rugged landscape tend to perform better than flatter ones. This paper uncovers this paradox and explains it by reaching back more than two centuries to the slave trades.

In Africa, between 1400 and 1900, four simultaneous slave trades - across the Atlantic, the Sahara Desert, the Red Sea, and the Indian Ocean-led to the forced migration of over 18 million people, with many more dying in the process (Africa's total population was roughly stable over this period at 50 million to 70 million). The economies they left behind were devastated: political institutions collapsed, and societies fragmented. For African people fleeing the slave trade, rugged terrain was a positive advantage. Enslavement generally took place through raids by one group on another, and hills, caves, and cliff walls provided lookout posts and hiding places for those trying to escape. Today, that same geographical ruggedness is an economic handicap, making it expensive to transport goods, raising the cost of irrigating and farming the land, and simply making it more expensive to do business.

We use the historical importance of terrain ruggedness within Africa to inform the debate that has arisen about the importance of geography for economic development. While it is commonly agreed that geography can have important consequences for economic outcomes, there is a growing debate over the channel of causality. The traditional focus

Received for publication November 5, 2009. Revision accepted for publication August 25, 2010.

* Nunn: Harvard University, NBER, and BREAD; Puga: IMDEA Social Sciences Institute and CEPR.

We are grateful for valuable comments from Ann Carlos, Edward Glaeser, Larry Katz, James Robinson, the Editor Dani Rodrik, two anonymous referees, and seminar participants. Both authors thank the Canadian Institute for Advanced Research (CIFAR) for its support. Funding from the Social Sciences and Humanities Research Council of Canada, the Comunidad de Madrid (PROCIUDAD-CM, s2007/HUM/0448), the European Commission's Seventh Research Framework Programme (grant agreement 225343, collaborative project HI-POD), Spain's Ministerio de Educación y Ciencia (SEJ2006-09993), and the Centre de Recerca en Economia Internacional is gratefully acknowledged. All the data necessary to reproduce the results of this paper are available at http://diegopuga.org/data/rugged/. has been on direct contemporaneous effects of geography on economic outcomes (Kamarck, 1976; Mellinger, Sachs, \& Gallup, 2000; Sachs, 2001; Gallup \& Sachs, 2001; Sachs \& Malaney, 2002; Rappaport \& Sachs, 2003). ${ }^{1}$ Recently others have argued for a more nuanced effect of geography on economic outcomes, which works through past interactions with key historical events (Diamond, 1997; Engerman \& Sokoloff, 1997, 2002; Sokoloff \& Engerman, 2000; Acemoglu, Johnson, \& Robinson, 2001; Acemoglu, Johnson, \& Robinson, 2002). For instance, Acemoglu et al. (2001) argue that the importance of a disease-prone environment for current income levels lies in the effect that it had on potential settler mortality during colonization. In areas where high mortality discouraged Europeans from settling, colonizers implemented poor institutions, which adversely affected subsequent economic development.

Generally it is difficult to estimate the historic indirect effects of geography. The difficulty arises because locations are generally affected not only by the historic effect of a geographical characteristic, but also by any direct effects that may exist today. Since geographic features are constant over time, disentangling the two channels is difficult. Our analysis exploits the fact that the long-term, positive effect of ruggedness, through fending off slave raiders, is concentrated in African countries, where the trades took place. Thus, we are able to identify the indirect historic effect of terrain ruggedness that works through the slave trade. We test further for this channel by using estimates, constructed by Nunn (2008), of the number of slaves taken from each country in Africa. ${ }^{2}$

We describe in section II how we measure terrain ruggedness (data sources for all other variables employed in the analysis are detailed in the appendix). Then, after introducing the econometric framework in section III, we investigate the relationship between ruggedness and income in section IV. We find strong evidence for a differential positive effect of the ruggedness in Africa that is both robust and highly significant. Looking within Africa, in section V, we provide evidence that the positive effect of ruggedness operates through the slave trades. We also estimate each of the coefficients for each of the channels implicit in the indirect effect of ruggedness. We find support for each of the underlying relationships: ruggedness negatively affects slave exports, and slave exports negatively affect the quality of domestic institutions, an important determinant of per capita income.

\footnotetext{
${ }^{1}$ The geographical characteristics that have been linked to economic outcomes include a disease-prone environment, proximity to the coast, and the prevalence of desert or tropical climate.

2 The figures are constructed by combining historical shipping records with slave inventories reporting slave ethnicities. Nunn (2008) finds that the slave trades had adverse effects on subsequent economic development because they weakened indigenous political structures and institutions, and promoted ethnic and political fragmentation.
} 


\section{Terrain Ruggedness}

Ruggedness has a number of effects on income that all regions of the world experience. The best-established of these are the contemporary negative effects of ruggedness. Irregular terrain makes cultivation difficult. On steep slopes, erosion becomes a potential hazard, and the control of water, such as irrigation, becomes much more difficult. According to the Food and Agriculture Organization (1993), when slopes are greater than 2 degrees, the benefits of cultivation often do not cover the necessary costs, and when slopes are greater than 6 degrees, cultivation becomes impossible. In addition, because of the very high costs involved in earthwork, building costs are much greater when terrain is irregular (Rapaport \& Snickars, 1999; Nogales, Archondo-Callao, \& Bhandari, 2002). As well, transportation over irregular terrain is slower and more costly. ${ }^{3}$

Our hypothesis is that within Africa, ruggedness had an additional historic effect because of Africa's history of the slave trades. In Africa, we expect terrain ruggedness also to have beneficial effects by having helped areas avoid the negative long-term consequences of the slave trades. The most common method of enslavement was through raids and kidnapping by members of one ethnicity on another or even between members of the same ethnicity (Northrup, 1978; Lovejoy, 2000). Rugged terrain afforded protection to those being raided. It provided caves for hiding and the ability to watch the lowlands and incoming paths. African historians have documented many examples of this. For instance, Bah (1976) describes how "throughout time, caverns, caves and cliff walls have served as places of refuge for people. . . . There are many examples of this defensive system in Africa. At Ebarak (south-eastern Senegal), there are still traces left of a tata wall near a cave in which the Bassaris, escaping from Fulani raids, hid." Writing about what is now Mali, Brasseur (1968) explains that "hidden in the uneven terrain, they [the Dogon] were able to use the military crests and, as far as the techniques of war at the time were concerned, were impregnable."4

When measuring terrain ruggedness, our purpose is to have a measure that captures small-scale terrain irregularities, such as caverns, caves, and cliff walls, that afforded protection to those being raided during the slave trades. We do so by calculating the terrain ruggedness index, originally devised by Riley, DeGloria, and Elliot (1999) to quantify topographic heterogeneity in wildlife habitats that provide hiding for prey and lookout posts. The main benefits of this measure are that it quantifies small-scale terrain irregularities, and it

\footnotetext{
${ }^{3}$ A study by Allen, Bourke, and Gibson (2005) highlights these negative effects of irregular terrain within Papua New Guinea. The authors show that steep terrain not only makes the production of cash crops very difficult, but it also makes it much more costly or even impossible to transport the crops to the markets. The result is that the populations living in these parts of Papua New Guinea have lower incomes and poorer health.

${ }^{4}$ For additional evidence, see Marchesseau (1945), Podlewski (1961), Gleave and Prothero (1971), Bah (1985, 2003), Cordell (2003), and Kusimba (2004).
}

Figure 1.-SChematic of The TerRain Ruggedness Calculation

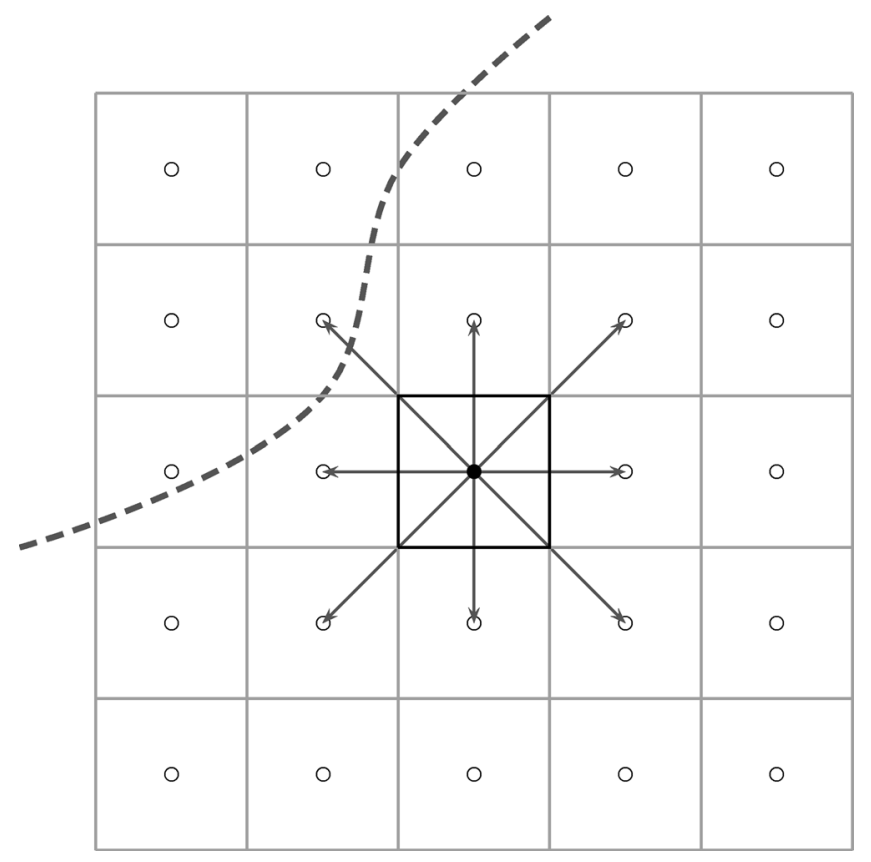

was designed to capture precisely the type of topographic features we are interested in. Other measures that economists and political scientists have used are typically constructed to capture the presence of large-scale terrain irregularitiesmountains in particular. ${ }^{5}$ Nevertheless, we will show that the results are robust to the use of alternative measures of terrain ruggedness.

Our starting point is GTOPO30 (U.S. Geological Survey, 1996), a global elevation data set developed through a collaborative international effort led by staff at the U.S. Geological Survey's Center for Earth Resources Observation and Science (EROS). Elevations in GTOPO30 are regularly spaced at 30-arc seconds across the entire surface of the earth on a map using a geographic projection. The sea-level surface distance between two adjacent grid points on a meridian is half a nautical mile or, equivalently, 926 meters.

Figure 1 represents 30-by-30 arc-second cells, with each cell centered on a point from the GTOPO30 elevation grid.

\footnotetext{
${ }^{5}$ For example, Gerrard (2000) constructs a measure of the percentage of each country that is covered by mountains, which is used by Fearon and Laitin (2003), Collier and Hoeffler (2004), and others in studies of civil war and conflict. Ramcharan (2006) uses data from the Center for International Earth Science Information Network (2003) on the percentage of each country within different elevation ranges in an instrumental-variables analysis of how economic diversification affects financial diversification. An exception to the focus on large-scale terrain irregularities is the article by Burchfield et al. (2006), who construct measures of both small-scale and large-scale irregularities and show that they have opposite effects on the scatteredness of residential development in U.S. metropolitan areas. Burchfield et al. measure small-scale terrain irregularities using the same terrain ruggedness index of Riley et al. (1999) that we use in this paper. Olken (2009) also uses small-scale terrain irregularities to compute a predicted measure of the signal strength of television transmissions to Indonesian villages in his study of the effects of television on social capital.
} 
The ruggedness calculation takes a point on the earth's surface like the one marked by a solid circle in the center of figure 1 and calculates the difference in elevation between this point and the point on the grid 30 arc-seconds north of it (the hollow circle directly above it in the figure). The calculation is performed for each of the eight major directions of the compass (north, northeast, east, southeast, south, southwest, west, and northwest). The terrain ruggedness index at the central point of figure 1 is given by the square root of the sum of the squared differences in elevation between the central point and the eight adjacent points. More formally, let $e_{r, c}$ denote elevation at the point located in row $r$ and column $c$ of a grid of elevation points. Then the terrain ruggedness index of Riley et al. (1999) at that point is calculated as $\sqrt{\sum_{i=r-1}^{r+1} \sum_{i=c-1}^{c+1}\left(e_{i, j}-e_{r, c}\right)^{2}}$. We then average across all grid cells in the country not covered by water to obtain the average terrain ruggedness of the country's land area. Since the sea-level surface that corresponds to a 30-by30 arc-second cell varies in proportion to the cosine of its latitude, when calculating the average terrain ruggednessor the average of any other variable - for each country, we weigh each cell by its latitude-varying sea-level surface.

The units for the terrain ruggedness index correspond to those used to measure elevation differences. In our calculation, ruggedness is measured in hundreds of meters of elevation difference for grid points 30 arc-seconds (926 meters on a meridian) apart. Examples of countries with an average ruggedness that corresponds to nearly level terrain are the Netherlands (terrain ruggedness 0.037) and Mauritania (0.115). Romania (1.267) and Zimbabwe (1.194) have mildly rugged terrain on average. Countries with terrain that is moderately rugged include Italy (2.458) and Djibouti (2.432). Highly rugged countries include Nepal (5.043) and Lesotho (6.202). Basic summary statistics for our ruggedness measure and correlations with other key variables are reported in an online appendix.

\section{Econometric Framework}

We now develop our estimation strategy for investigating the relationship among ruggedness, the slave trade, and income. Our starting hypothesis is that ruggedness has an effect on current income that is the same for all parts of the world. This relationship can be written as

$$
y_{i}=\kappa_{1}-\alpha r_{i}+\beta q_{i}+e_{i},
$$

where $i$ indexes countries; $y_{i}$ is income per capita; $r_{i}$ is our measure of ruggedness; $q_{i}$ is a measure of the efficiency or quality of the organization of society; $\kappa_{1}, \alpha$, and $\beta$ are constants $(\alpha>0$ and $\beta>0)$; and $e_{i}$ is a classical error term (we assume that $e_{i}$ is independent and identically distributed, drawn from a normal distribution, with a conditional expectation of 0 ).

In equation (1), we assume that the common impact of ruggedness on income is negative. This is not important for the exposition; it simply anticipates our empirical findings of a negative common effect of ruggedness. In reality, an important part of $-\alpha$ is the effect of ruggedness on income through increased costs of cultivation, building, and trade. However, $-\alpha$ may also contain persistent historic effects of ruggedness that are similar across regions. For example, rugged terrain may be correlated with historic deposits of precious minerals, which may have had long-term effects by affecting historic institutions (Dell, 2010).

Historical studies and the empirical work of Nunn (2008) have documented that Africa's slave trades adversely affected the political and social structures of societies. We capture this effect of Africa's slave trades with

$$
q_{i}= \begin{cases}\kappa_{2}-\gamma x_{i}+u_{i} & \text { if } i \text { is in Africa, } \\ u_{i} & \text { otherwise, }\end{cases}
$$

where $x_{i}$ denotes slave exports, $\kappa_{2}$ and $\gamma$ are constants $(\gamma>0)$, and $u_{i}$ is a classical error term.

Historical accounts argue that the number of slaves taken from an area was reduced by the ruggedness of the terrain. This relationship is given by

$$
x_{i}=\kappa_{3}-\lambda r_{i}+v_{i},
$$

where $\kappa_{2}$ and $\lambda$ are constants $(\lambda>0)$ and $v_{i}$ is a classical error term.

Equations (1), (2), and (3) are the core relationships in our analysis. Our first approach is to combine all three by substituting equations (2) and (3) into (1), which gives

$$
y_{i}= \begin{cases}\kappa_{1}-\alpha r_{i}+\beta \gamma \lambda r_{i}+\kappa_{4}+\zeta_{i}+\xi_{i} & \text { if } i \text { is in Africa, } \\ \kappa_{1}-\alpha r_{i}+\zeta_{i} & \text { otherwise, }\end{cases}
$$

where $\kappa_{4} \equiv \beta\left(\kappa_{2}-\gamma \kappa_{3}\right), \zeta_{i} \equiv e_{i}+\beta u_{i}$ and $\xi_{i} \equiv-\beta \gamma v_{i}$. Equation (4) summarizes the relationships between ruggedness, the slave trades, and current income. It illustrates the core hypothesis of this paper: that for African countries, there is an additional positive historic effect of ruggedness on income that works through the slave trades $\beta \gamma \lambda$.

Guided by equation (4), we estimate the following relationship between ruggedness and income:

$$
y_{i}=\beta_{0}+\beta_{1} r_{i}+\beta_{2} r_{i} I_{i}^{\text {Africa }}+\beta_{3} I_{i}^{\text {Africa }}+\varepsilon_{i},
$$

where $I_{i}^{\text {Africa }}$ is an indicator variable that equals 1 if $i$ is in Africa and 0 otherwise.

Combining our predictions about the relationships among ruggedness, the slave trades, and income yields a first hypothesis, which is core to our paper: ${ }^{6}$

Hypothesis 1. $\beta_{2}>0$ (in Africa, ruggedness has an additional positive effect on income).

6 We have implicitly assumed that $\beta_{2}$ is the same for all African countries. In section IV, we relax this assumption and allow the indirect effect of ruggedness to differ across the regions of Africa. 
We have assumed throughout that the conditional expectation of each of the error terms in equations (1) to (3) is equal to 0 . In this case, estimating equation (5) provides a consistent estimate of the historic effect of ruggedness in Africa. In practice, our assumptions rely on there not being variables that belong in any of the structural equations (1) to (3), but are omitted from our reduced-form estimating equation (5). More specifically, in order for an omitted variable to bias our coefficient of interest- $\beta_{2}$ in equation (5) - it must be the case that either the relationship between income and the omitted factor is different inside and outside Africa or that the relationship between the omitted factor and ruggedness is different inside and outside Africa. For this reason, in our empirical analysis, we pay particular attention to identifying and including potentially omitted factors for which the relationship with either income or ruggedness is potentially different inside and outside Africa.

Equation (5) illustrates the relationship between income and ruggedness, leaving slave exports in the background. Recall that we arrived at this equation by substituting equations (3) and (2) into equation (1). In section V, we bring slave exports to the foreground by instead substituting only equation (2) into (1) and estimating equation (3) separately. This gives us a relationship between income and both ruggedness (now only incorporating its common effect) and slave exports:

$$
y_{i}= \begin{cases}\kappa_{1}-\alpha r_{i}+\beta \kappa_{2}-\beta \gamma x_{i}+\zeta_{i} & \text { if } i \text { is in Africa } \\ \kappa_{1}-\alpha r_{i}+\zeta_{i} & \text { otherwise. }\end{cases}
$$

We test this relationship and equation (3) by estimating the following equations (note that for all non-African countries, slave exports are 0: $\left.x_{i}=0\right)$ :

$$
\begin{aligned}
& y_{i}=\beta_{6}+\beta_{7} r_{i}+\beta_{8} r_{i} I_{i}^{\text {Africa }}+\beta_{9} I_{i}^{\text {Africa }}+\beta_{10} x_{i}+\varepsilon_{i}, \\
& x_{i}=\beta_{11}+\beta_{12} r_{i}+\epsilon_{i} .
\end{aligned}
$$

Estimating equations (7) and (8) allows us to test four additional hypotheses:

Hypothesis 2 . $\beta_{12}<0$ (ruggedness negatively affects slave exports).

Hypothesis 3. $\beta_{10}<0$ (slave exports negatively affect income).

Hypothesis 4. $\beta_{8}=0$ (once slave exports are taken into account, the effect of ruggedness is no different in Africa).

Hypothesis 5. $\beta_{7}=-\alpha$ (once slave exports are taken into account, the coefficient on ruggedness provides a consistent estimate of the common effect of ruggedness).

Hypothesis 2 and 3 are that ruggedness deterred slave exports and that slave exports are negatively related to current income. Hypothesis 4 provides a way of testing whether the slave trades can fully account for the positive indirect effect of ruggedness within Africa. If the relationship between ruggedness and income is different for Africa only because of the slave trades, then once we control for the effect of the slave trades on income, there should no longer be a differential effect of ruggedness for Africa. Hypothesis 5 states that taking into account the indirect effect of ruggedness by controlling for the slave trades yields a consistent estimate of the common effect of ruggedness.

\section{The Differential Effect of Ruggedness in Africa}

As a first step in our empirical analysis, we now estimate the common effect of ruggedness on income per person and its differential effect for Africa. Our baseline estimates of equation (5) are given in table 1. Looking first at column 1, when we estimate equation (5) by regressing income per person on ruggedness while allowing for a differential effect in African countries, we find that the coefficient for ruggedness is negative and statistically significant: $\beta_{1}<0$ in equation (5). This indicates a negative common effect of ruggedness for the world as a whole. This is consistent with ruggedness negatively affecting income by increasing the costs of trade, construction, and agriculture. Although we cannot rule out the existence of some positive common consequences of ruggedness, we find that the net common effect is negative.

The coefficient estimate for ruggedness interacted with an indicator variable for Africa is positive and statistically significant: $\beta_{2}>0$ in equation (5). This differential effect for Africa is consistent with hypothesis 1 . Within Africa, there is an additional positive effect of ruggedness on income.

\section{A. Robustness with Respect to Omitted Geographical Variables}

When interpreting our core results regarding the relationship between ruggedness and current economic outcomes, a possible source of concern is that the estimated differential effect of ruggedness within Africa may be driven, at least in part, by other geographical features. However, for an omitted variable to bias our estimated differential effect, it is not enough that the omitted variable is correlated with income and ruggedness. It must be the case that either the relationship between the omitted factor and income is different within and outside Africa, or the relationship between the omitted factor and ruggedness is different within and outside Africa. Thus, to deal with potentially omitted differential effects, we include in our baseline specification of column 1 both the control variable and an interaction of the control variable with our Africa indicator variable. By doing this, we allow the effect of the control variable to differ for Africa.

A potentially confounding factor, which may have differential effects within and outside Africa, is the curse of mineral resources (Sachs \& Warner, 2001; Mehlum, Moene, $\&$ Torvik, 2006). If diamond deposits are correlated with ruggedness, and diamond production increases income outside Africa but decreases income within Africa because of poor institutions, then this could potentially bias the estimated 
TABle 1.- The Differential EFFECT OF RugGednESS IN AFriCA

\begin{tabular}{|c|c|c|c|c|c|c|}
\hline & \multicolumn{6}{|c|}{ Dependent Variable: Log Real GDP per Person, 2000} \\
\hline & (1) & (2) & (3) & (4) & $(5)$ & (6) \\
\hline Ruggedness & $\begin{array}{l}-0.203 \\
(0.093)^{* *}\end{array}$ & $\begin{array}{l}-0.196 \\
(0.094)^{* *}\end{array}$ & $\begin{array}{l}-0.203 \\
(0.094)^{* *}\end{array}$ & $\begin{array}{l}-0.243 \\
(0.092)^{* * *}\end{array}$ & $\begin{array}{l}-0.193 \\
(0.081)^{* *}\end{array}$ & $\begin{array}{l}-0.231 \\
(0.077)^{* * *}\end{array}$ \\
\hline Ruggedness $\times I^{\text {Africa }}$ & $\begin{array}{l}0.393 \\
(0.144)^{* * *}\end{array}$ & $\begin{array}{c}0.404 \\
(0.146)^{* * *}\end{array}$ & $\begin{array}{l}0.406 \\
(0.138)^{\text {*** }}\end{array}$ & $\begin{array}{c}0.414 \\
(0.157)^{\text {*** }}\end{array}$ & $\begin{array}{c}0.302 \\
(0.130)^{* *}\end{array}$ & $\begin{array}{l}0.321 \\
(0.127)^{* *}\end{array}$ \\
\hline$I^{\text {Africa }}$ & $\begin{array}{l}-1.948 \\
(0.220)^{* * *}\end{array}$ & $\begin{array}{l}-2.014 \\
(0.222)^{* * *}\end{array}$ & $\begin{array}{l}-1.707 \\
(0.325)^{* * *}\end{array}$ & $\begin{array}{l}-2.066 \\
(0.324)^{\text {*** }}\end{array}$ & $\begin{array}{l}-1.615 \\
(0.295)^{* * *}\end{array}$ & $\begin{array}{l}-1.562 \\
(0.415)^{* * *}\end{array}$ \\
\hline Diamonds & & $\begin{array}{c}0.017 \\
(0.012)\end{array}$ & & & & $\begin{array}{l}0.028 \\
(0.010)^{* * *}\end{array}$ \\
\hline Diamonds $\times I^{\text {Africa }}$ & & $\begin{array}{r}-0.014 \\
(0.012)\end{array}$ & & & & $\begin{array}{l}-0.026 \\
(0.011)^{* *}\end{array}$ \\
\hline$\%$ Fertile soil & & & $\begin{array}{c}0.000 \\
(0.003)\end{array}$ & & & $\begin{array}{r}-0.002 \\
(0.003)\end{array}$ \\
\hline$\%$ Fertile soil $\times I^{\text {Africa }}$ & & & $\begin{array}{r}-0.008 \\
(0.006)\end{array}$ & & & $\begin{array}{r}-0.009 \\
(0.007)\end{array}$ \\
\hline$\%$ Tropical climate & & & & $\begin{array}{l}-0.007 \\
(0.002)^{* * *}\end{array}$ & & $\begin{array}{l}-0.009 \\
(0.002)^{* * *}\end{array}$ \\
\hline$\%$ Tropical climate $\times I^{\text {Africa }}$ & & & & $\begin{array}{c}0.004 \\
(0.004)\end{array}$ & & $\begin{array}{c}0.006 \\
(0.004)\end{array}$ \\
\hline Distance to coast & & & & & $\begin{array}{l}-0.657 \\
(0.177)^{* * *}\end{array}$ & $\begin{array}{l}-1.039 \\
(0.193)^{* * *}\end{array}$ \\
\hline Distance to coast $\times I^{\text {Africa }}$ & & & & & $\begin{array}{c}-0.291 \\
(0.360)\end{array}$ & $\begin{array}{c}-0.194 \\
(0.386)\end{array}$ \\
\hline Constant & $\begin{array}{l}9.223 \\
(0.143)^{* * *}\end{array}$ & $\begin{array}{l}9.204 \\
(0.148)^{* * *}\end{array}$ & $\begin{array}{l}9.221 \\
(0.200)^{* * *}\end{array}$ & $\begin{array}{l}9.514 \\
(0.164)^{* * *}\end{array}$ & $\begin{array}{l}9.388 \\
(0.134)^{* * *}\end{array}$ & $\begin{array}{l}9.959 \\
(0.195)^{* * *}\end{array}$ \\
\hline Observations & 170 & 170 & 170 & 170 & 170 & 170 \\
\hline$R^{2}$ & 0.357 & 0.367 & 0.363 & 0.405 & 0.421 & 0.537 \\
\hline
\end{tabular}

differential effect of ruggedness. ${ }^{7}$ Column 2 adds to our baseline specification of column 1 a control variable measuring carats of gem-quality diamonds extracted per square kilometer between 1958 and 2000 (see the Data Appendix for details of how this and other geographical controls are constructed), as well as an interaction of this control with the Africa indicator variable. We find weak evidence that the effect of diamonds is positive in general, but that for African countries, there is a differential negative effect that nearly wipes out the general positive effect (however, neither effect is statistically significant unless we include other controls as in column 6). The inclusion of this control variable and its interaction with the Africa indicator variable does not alter our results regarding the relationship between ruggedness and current economic outcomes. We have also tried controlling for other mineral resources, such as oil reserves and gold (together with an African interaction term). The results are unaffected by the inclusion of these additional controls.

It is also possible that in general, rugged areas have worse soil quality, but within Africa, rugged areas have better soil quality. For example, the Rift Valley region of Africa is rugged but has very fertile soil. To control for this possibility, we construct a measure of the percentage of fertile soil in each country. This is defined as soil that is not subject to severe constraints for growing rain-fed crops in terms of soil fertility, depth, chemical and drainage properties, or moisture

\footnotetext{
${ }^{7}$ See Mehlum et al. (2006) and Robinson, Torvik, and Verdier (2006) for theory and empirical evidence supporting such a differential effect of resource endowments.
}

storage capacity and is based on the FAO/UNESCO Digital Soil Map of the World. In column 3, we add the measure of soil fertility and its interaction with the Africa indicator variable to our baseline specification. The results show that the differential effect of ruggedness remains robust to controlling for soil quality.

A related argument can be made about tropical diseases. If rugged areas are less prone to tropical diseases within Africa but not in the rest of the world, then this could potentially bias the estimated differential effect of ruggedness. To check for this possibility, we add to our baseline specification in column 4 a variable measuring the percentage of each country that has any of the four tropical climates in the Köppen-Geiger climate classification, as well as an interaction of this variable with the Africa indicator variable. We see that there is a statistically significant negative relationship between tropical climate and income, but that the effect is no different for African countries. Our core results are, once again, unchanged.

We recognize that alternative proxies for tropical diseases are also possible. For example, one can focus specifically on malaria and include an index of the stability of malaria transmission from Kiszewski et al. (2004) and the corresponding African interaction. When we do this, our core results remain unchanged. The same is also true if we control for the distance to the equator and the corresponding African interaction.

Motivated by the arguments of Rappaport and Sachs (2003) and others that coastal access is a fundamental determinant of income differences, in column 5 we control for the average distance (measured in thousands of kilometers) to the nearest 
ice-free coast for each country. As before, we also include an interaction of the distance variable with the African indicator variable. Our results remain robust. Finally, in column 6, we include all of the geographic controls and their corresponding interaction terms. We find again that our baseline results from column 1 are robust to controlling for other geographic characteristics that could have a differential effect in Africa. ${ }^{8}$

\section{B. Robustness with Respect to Alternative Income and Ruggedness Measures}

We next consider a number of sensitivity checks to ensure that the findings documented to this point are in fact robust. First, one can think of many alternative measures of ruggedness. We have chosen to use a well-established measure of terrain ruggedness that Riley et al. (1999) developed to quantify topographic heterogeneity that creates hiding places and outlook posts in wildlife habitats. The first robustness check that we perform is to ensure that our results hold using other measures of ruggedness. The first alternative measure we consider is the average absolute value of the slope of the terrain. Thus, using the same GTOPO30 elevation data, we calculate the average uphill slope of the country's surface area. ${ }^{9}$ Our second alternative measure is the average standard deviation of elevation within the same eight-cell neighborhood. The third measure is motivated by the possibility that what matters is having a large enough amount of sufficiently rugged terrain nearby, even if some portions of the country are fairly flat. To capture this logic, we calculate the percentage of a country's land area that is highly rugged. ${ }^{10}$ All of these measures treat land uniformly when averaging over cells to construct country averages. Thus, they do not capture the possibility that ruggedness may be more important (and thus should be given more weight) in areas that are more densely populated today. Therefore, our final alternative measure is a population-weighted measure of ruggedness. We start by calculating the ruggedness of each 30-by-30 arc-second cell, but in averaging this for each country, we weight ruggedness in each cell by the share of the country's population located in that cell. ${ }^{11}$

\footnotetext{
${ }^{8}$ Of independent interest is the relationship between ruggedness and our set of control variables. We do not find a significant relationship between ruggedness and either diamond production, soil fertility, or distance from the coast. We do find a negative relationship between ruggedness and the fraction of a country that has a tropical climate. As well, we do not find Africa to be significantly more or less rugged than the rest of the world.

${ }^{9}$ For every point on the 30 arc-seconds grid, we calculate the absolute value of the slope between the point and the eight adjacent points. The absolute values of the eight slopes are then averaged to calculate the mean uphill slope for each 30-by-30 arc-second cell. We then average across all grid cells in a country not covered by water to obtain the average uphill slope of the country's land area. Again, our calculations take into account the latitude-varying sea-level surface that corresponds to the 30-by-30 arcsecond cell centered on each point.

${ }^{10}$ We use a threshold set at 240 meters for the terrain ruggedness index calculated on the 30 arc-seconds grid, below which Riley et al. (1999) classify terrain as being level to intermediately rugged.

11 The population data are for 2000 and are from the LandScan data set (Oak Ridge National Laboratory, 2001).
}

The second robustness check that we perform is a test of whether our results are robust when we consider income from other time periods. When looking at time periods earlier than 2000, we turn to data from Maddison (2007), which has much better historic coverage than the World Bank. ${ }^{12}$ We find that our results are robust using income from any year between 1950 and 2000 or for average annual income between 1950 and 2000.

We reestimate our baseline estimating equation with the full set of controls - the specification in column 6 in table 1 using all the different combinations of the income and ruggedness measures. We find that the estimated positive differential effect of ruggedness is very robust. In all regressions, we find that the differential effect of ruggedness within Africa is positive and statistically significant. ${ }^{13}$

\section{Robustness with Respect to Influential Observations}

Next, we check whether the results from table 1 are driven by some particularly influential outliers. Figure 2 shows a scatter plot of income per person against ruggedness for African countries (top panel) and non-African countries (bottom panel). In these plots of the raw data, one observes a positive relationship for African countries and a negative relationship for non-African countries. However, a number of observations appear as clear outliers in terms of their ruggedness. Our first sensitivity check estimates our baseline specification, with our full set of control variables, after dropping the ten most rugged countries. The results are presented in column 1 of table 2 .

In the scatter plot, one can also observe that small countries (based on land area) tend to have either unusually high ruggedness (for example, Seychelles, identified in the figure by its ISO 3166-1 code SYC) or low ruggedness (for example, Saint Kitts and Nevis, KNA). Given this, we perform a second robustness check where the ten smallest countries are omitted from the sample. The estimates are reported in column 2 of table 2.14

We next adopt a more systematic approach to deal with influential observations and remove influential observations using each observation's DFBETA, a measure of the difference in the estimated coefficient for the ruggedness interaction (scaled by the standard error) when the observation is included and when it is excluded from the sample. Following Belsley, Kuh, and Welsch (1980), we omit all observations for which $\mid$ DFBETA $_{i} \mid>2 / \sqrt{N}$, where $N$ is the number of

\footnotetext{
${ }^{12}$ For 2000, Maddison (2007) has data for only 159 countries, compared to 170 for the World Bank. But once one starts to move back in time, Maddison's coverage is much better than the World Bank's. For example, prior to 1980, the World Bank does not have data on real per capita PPPadjusted GDP. Maddison has data for 137 countries as far back as 1950.

${ }^{13}$ For brevity, we do not report the results here. See the online appendix for the complete results.

${ }^{14}$ A related concern is that our results may be driven by atypical African countries, such as island countries or North African countries. Our results are also robust to omitting these countries from the sample.
} 
Figure 2.-INCOME AND RUGgEDNESS AMONG AFRICAN AND NON-AFRICAN COUNTRIES

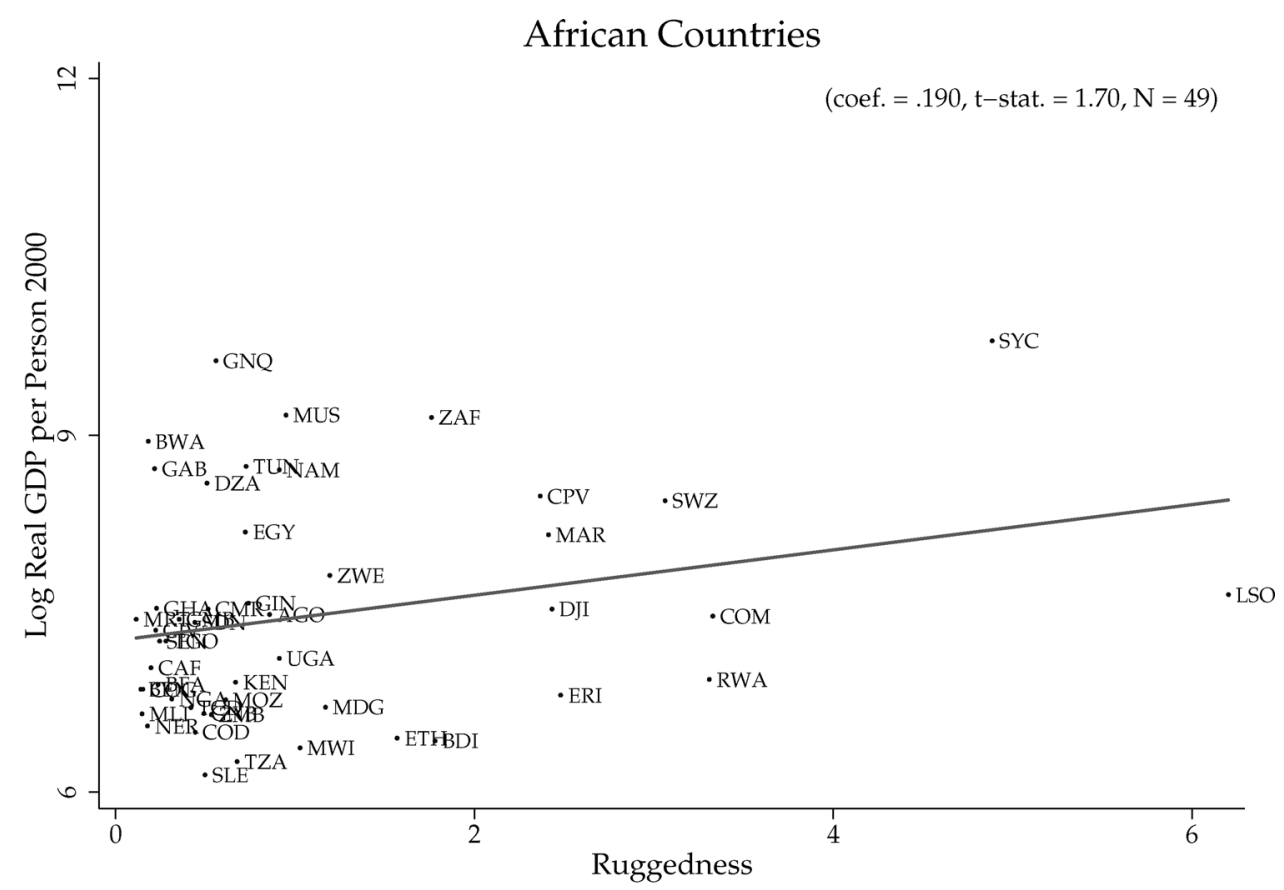

Non-African Countries

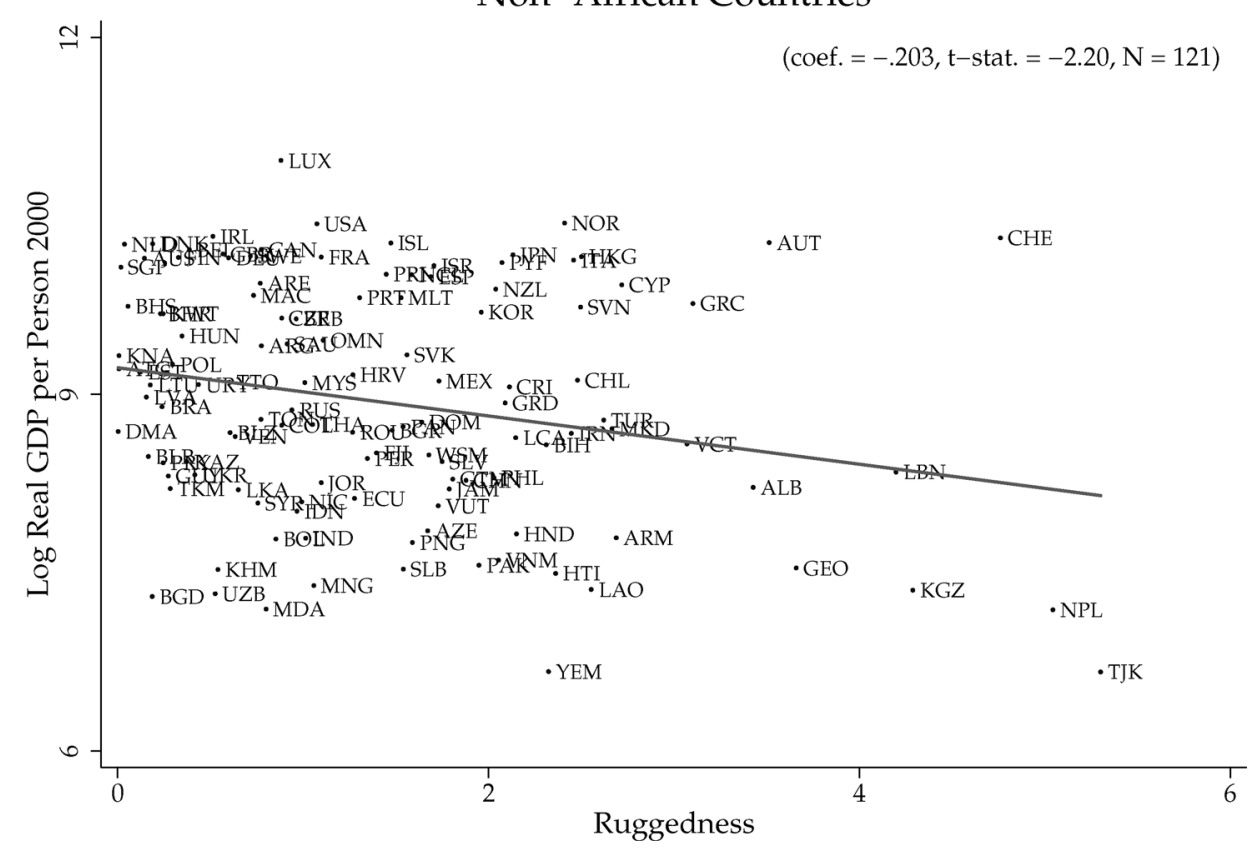

observations - in our case, $170 .{ }^{15}$ Results are presented in column 3 of table 2 .

In all three of the regressions with omitted observations, the ruggedness coefficient remains negative and statistically significant, and the ruggedness interaction remains positive

${ }^{15}$ Using other measures and rules for the omission of influential observations, such as DFITS, Cook's distance, or Welsch distance, provides very similar results. and statistically significant, confirming the existence of a differential effect of ruggedness within Africa.

In figure 2, a small number of observations appear as particularly influential because the ruggedness measure is skewed to the left, leaving a small number of observations with large values. We remedy this in two ways. First, we take the natural log of ruggedness and use this in the estimating equations. This draws in the outlying observations in the regression. The estimates of interest, reported in column 4 in table 2, 
TABLE 2.-ROBUSTNESS WITH RESPECT TO INFLUENTIAL OBSERVATIONS

\begin{tabular}{|c|c|c|c|c|c|}
\hline & \multicolumn{5}{|c|}{ Dependent Variable: Log Real GDP per Person, 2000} \\
\hline & $\begin{array}{c}\text { Omit } 10 \\
\text { Most Rugged }\end{array}$ & $\begin{array}{l}\text { Omit } 10 \\
\text { Smallest }\end{array}$ & $\begin{array}{c}\text { Omit if } \\
\mid \text { DFBETA } \mid>2 / \sqrt{N}\end{array}$ & $\begin{array}{c}\text { Using } \\
\text { ln(Ruggedness) }\end{array}$ & $\begin{array}{c}\text { Box-Cox Transformation } \\
\text { of Ruggedness }\end{array}$ \\
\hline & (1) & (2) & (3) & (4) & (5) \\
\hline Ruggedness & $\begin{array}{l}-0.202 \\
(0.083)^{* *}\end{array}$ & $\begin{array}{l}-0.221 \\
(0.083)^{* * *}\end{array}$ & $\begin{array}{l}-0.261 \\
(0.068)^{* * *}\end{array}$ & $\begin{array}{l}-0.171 \\
(0.051)^{* * *}\end{array}$ & $\begin{array}{l}-0.249 \\
(0.075)^{* * *}\end{array}$ \\
\hline Ruggedness $\times I^{\text {Africa }}$ & $\begin{array}{l}0.286 \\
(0.133)^{* *}\end{array}$ & $\begin{array}{l}0.188 \\
(0.099)^{*}\end{array}$ & $\begin{array}{l}0.223 \\
(0.116)^{*}\end{array}$ & $\begin{array}{l}0.234 \\
(0.119)^{* *}\end{array}$ & $\begin{array}{l}0.333 \\
(0.142)^{* *}\end{array}$ \\
\hline$I^{\text {Africa }}$ & $\begin{array}{l}-1.448 \\
(0.454)^{* * *}\end{array}$ & $\begin{array}{l}-1.465 \\
(0.405)^{* * *}\end{array}$ & $\begin{array}{l}-1.510 \\
(0.406)^{* * *}\end{array}$ & $\begin{array}{l}-1.083 \\
(0.394)^{* * *}\end{array}$ & $\begin{array}{l}-1.139 \\
(0.391)^{* * *}\end{array}$ \\
\hline All controls & Yes & Yes & Yes & Yes & Yes \\
\hline Observations & 160 & 160 & 164 & 170 & 170 \\
\hline$R^{2}$ & 0.520 & 0.545 & 0.564 & 0.527 & 0.533 \\
\hline
\end{tabular}

Coefficients are reported with robust standard errors in brackets. ${ }^{* * *},{ }^{* *}$, and ${ }^{*}$ indicate significance at the $1 \%, 5 \%$, and $10 \%$ levels. All regressions include a constant, and our full set of control variables: diamonds, diamonds $\times I^{\text {Africa }}, \%$ fertile soil, $\%$ fertile soil $\times I^{\text {Africa }}, \%$ tropical climate, $\%$ tropical climate $\times I^{\text {Africa }}$, distance to coast, and distance to coast $\times I^{\text {Africa }}$. Coefficients and standard errors for the control variable are reported in the online appendix.

remain robust to this transformation. However, looking at the natural log of ruggedness variable, one finds that the measure is no longer left skewed; it is now right skewed, with a small number of influential observations taking on very small values. Because of this, we pursue a second strategy where we perform a zero-skewness Box-Cox power transformation on the ruggedness variable to obtain a measure with zero skewness. The relationships between income and the zeroskewness ruggedness measure are shown in figure 3 . It is evident that the relationships between income and ruggedness using the zero-skewness measure do not feature influential, outlying observations. In addition, a different relationship within Africa and outside Africa is still apparent in the scatter plots of the data. Estimates using the zero-skewness measure are reported in column 5. The estimates confirm the impression given by the figures. There is a positive and significant differential effect of ruggedness within Africa.

\section{Do Other African Characteristics or Colonial Rule Explain the Differential Effect of Ruggedness?}

A final possible source of concern is that the differential effect of ruggedness for Africa is not really an African effect. Perhaps it arises because the effect of ruggedness on income differs for areas with some geographic characteristic that happens to be particularly prevalent in Africa. For instance, it could be that in countries where a large fraction of the territory experiences tropical climates, rugged areas are cooler, dryer, or even less prone to tropical diseases. If tropical climates are particularly prevalent in Africa (they characterize $34.0 \%$ of land in Africa compared with $19.3 \%$ of the rest of the world, excluding Antarctica), perhaps the interaction between ruggedness and the Africa indicator is proxying for an interaction between ruggedness and tropical climates. Similarly, it could be that in countries where a large fraction of the territory is covered by dry, unfertile soil like desert, rugged areas are less arid. If areas with poor soil are particularly prevalent in Africa (fertile soil comprises $22.5 \%$ of the land in Africa compared with $25.3 \%$ in the rest of the world, excluding Antarctica), perhaps the interaction between ruggedness and the Africa indicator is proxying for an interaction between ruggedness and poor soil quality.

We consider these possibilities in columns 1 to 3 of table 3, where we add to our baseline estimating equation variables measuring the percentage of each country with tropical climates and the percentage of each country with fertile soil (these can be seen as playing the same role as the Africa indicator), as well as interactions between ruggedness and these two variables (these can be seen as playing the same role as the interaction between ruggedness and the Africa indicator). ${ }^{16}$ In columns 1 and 2 , we include each of the two sets of controls one at a time, and in column 3, we include them together. The coefficients of interest, measuring the common effect of ruggedness and the differential effect for Africa, change little and remain statistically significant. ${ }^{17}$

We next consider the possibility that our Africa indicator variable may be picking up the prevalence of colonial rule. In areas that were colonized, rugged terrain may have provided a way to defend against colonial rule. Since a greater proportion of countries in Africa, relative to the rest of the world, experienced colonial rule (within Africa, $89.5 \%$ of the countries were colonized, while outside Africa, this figure is $44.1 \%$ ), the differential effect of ruggedness in Africa may be biased by a differential effect of ruggedness in countries that were colonized.

We control for this possibility in columns 4 and 5 of table 3 . In column 4, we include five indicator variables for the identity of a country's colonizer, with the omitted category being

\footnotetext{
16 The results are also robust if we use a measure of the proportion of a country's land that is desert rather than the proportion with fertile soil.

17 One could also think that certain countries, because of inferior access to technology or poor governance, are worse equipped to mitigate the common negative effects of ruggedness. However, note that this would work against estimating a positive differential effect of ruggedness within Africa, since access to technology and governance is likely to be worse on average in Africa. A further concern is that the tropical climate measure is potentially endogenous to ruggedness, since some areas may not be classified as tropical if they are rugged. A preferable measure would quantify how tropical a climate would be if it were not rugged. Using a country's distance from the equator as a proxy for this measure yields very similar results.
} 
Figure 3.-InCOME AND Ruggedness (BoX-COX TrANSFORMEd) AMONG AFrICAN AND NON-AFRICAN COUNTRIES
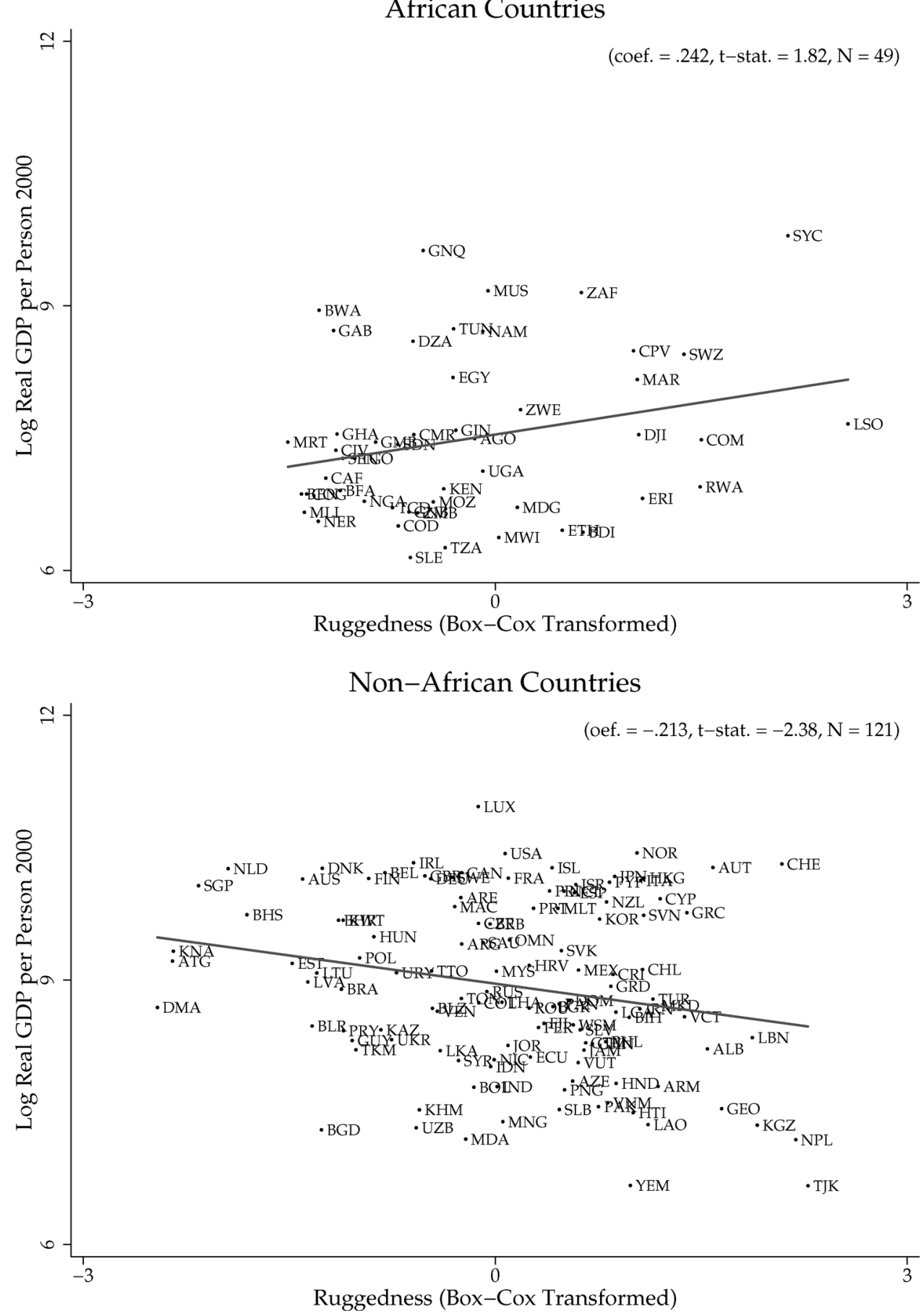

for countries that were not colonized. ${ }^{18} \mathrm{We}$ also include the set of colonizer indicator variables interacted with ruggedness. The differential effect of ruggedness remains positive and statistically significant.

Numerous studies have shown that differences in the legal origin of the colonizing powers are an important determinant

18 The five categories for the identity of the colonizer are British, Portuguese, French, Spanish, and other European. of a variety of country characteristics, including financial development, labor market regulations, contract enforcement, and economic growth (La Porta, Lopez-de-Silanes, \& Shleifer, 2008). Given the particular strong impact of colonial rule that works through legal origin, we also control directly for each country's legal origin by including four legal origin indicator variables and their interactions with ruggedness. The four indicators are for French, German, Scandinavian, and socialist legal origins, with the omitted category being 


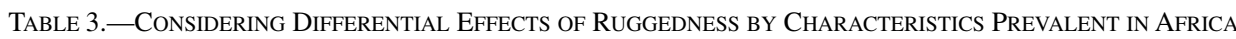

\begin{tabular}{|c|c|c|c|c|c|}
\hline & \multicolumn{5}{|c|}{ Dependent Variable: Log Real GDP per Person, 2000} \\
\hline & (1) & (2) & (3) & (4) & (5) \\
\hline Ruggedness & $\begin{array}{l}-0.259 \\
(0.101)^{* *}\end{array}$ & $\begin{array}{l}-0.322 \\
(0.160)^{* *}\end{array}$ & $\begin{array}{l}-0.374 \\
(0.161)^{* *}\end{array}$ & $\begin{array}{l}-0.386 \\
(0.176)^{* *}\end{array}$ & $\begin{array}{l}-0.543 \\
(0.179)^{* * *}\end{array}$ \\
\hline Ruggedness $\times I^{\text {Africa }}$ & $\begin{array}{l}0.357 \\
(0.130)^{* * *}\end{array}$ & $\begin{array}{l}0.400 \\
(0.155)^{* * *}\end{array}$ & $\begin{array}{l}0.360 \\
(0.140)^{* *}\end{array}$ & $\begin{array}{l}0.399 \\
(0.203)^{* *}\end{array}$ & $\begin{array}{l}0.435 \\
(0.135)^{* * *}\end{array}$ \\
\hline$I^{\text {Africa }}$ & $\begin{array}{l}-1.814 \\
(0.213)^{* * *}\end{array}$ & $\begin{array}{l}-1.977 \\
(0.223)^{* * *}\end{array}$ & $\begin{array}{l}-1.818 \\
(0.218)^{* * *}\end{array}$ & $\begin{array}{l}-1.740 \\
(0.337)^{* * *}\end{array}$ & $\begin{array}{l}-1.994 \\
(0.216)^{* * *}\end{array}$ \\
\hline Ruggedness $\times \%$ tropical climate & Yes & No & Yes & Yes & Yes \\
\hline$\%$ Tropical climate & Yes & No & Yes & Yes & Yes \\
\hline Ruggedness $\times \%$ fertile soil & No & Yes & Yes & Yes & Yes \\
\hline$\%$ Fertile soil & No & Yes & Yes & Yes & Yes \\
\hline Ruggedness $\times$ colonizer FEs & No & No & No & Yes & No \\
\hline Colonizer FEs & No & No & No & Yes & No \\
\hline Ruggedness $\times$ legal origin FEs & No & No & No & No & Yes \\
\hline Legal origin FEs & No & No & No & No & Yes \\
\hline Observations & 170 & 170 & 170 & 170 & 170 \\
\hline$R^{2}$ & 0.404 & 0.363 & 0.408 & 0.430 & 0.559 \\
\hline
\end{tabular}

Coefficients are reported with robust standard errors in brackets. ${ }^{* * *},{ }^{* *}$, and ${ }^{*}$ indicate significance at the $1 \%, 5 \%$, and $10 \%$ levels.

British legal origin. The positive differential effect of ruggedness remains when accounting for differences in countries' legal origins.

\section{E. Differential Effects of Ruggedness across Regions within Africa}

One concern with the results presented to this point is that we allow only the effect of ruggedness on economic outcomes to differ for African countries. We have also checked whether one also finds a positive and statistically significant differential effect of ruggedness within other parts of the world. Treating other continents in the exact same manner that we have treated Africa in equation (5) (including a continent indicator and an indicator interacted with ruggedness), we find that for no other continent is there a positive and statistically significant differential effect of ruggedness. In other words, the positive differential effect of ruggedness is unique to Africa, and is not found in North America, South America, Europe, Asia, or Oceania.

Having determined that the differential effect of ruggedness is specific to the African continent, we examine whether the strength of the effect differs across the regions within Africa in a manner that is consistent with the known history of the slave trades. Our argument is that ruggedness has a differential positive effect within Africa because no other continent was subject to the slave trades that devastated Africa between 1400 and 1900. However, the exposure to the slave trades was not uniform across the continent. West Africa was the region most severely affected by the slave trades, whereas North Africa was barely touched. ${ }^{19}$ Thus, the

\footnotetext{
${ }^{19}$ The correlation between our measure of slave exports, described in detail in the next section, and a West Africa indicator variable is 0.53 and is statistically significant. The correlation between slave exports and a North Africa indicator variable is -0.30 and is also statistically significant. For all other African regions, the correlation between slave exports and a region indicator variable is not statistically different from 0 .
}

logic of our core argument suggests that ruggedness should have a more beneficial effect within West Africa, where the threat of being enslaved was greatest, but within North Africa, where slave capture was nearly absent, the effect should be much smaller and not very different from that in the rest of the world. To check this, we examine the five regions of Africa defined by Bratton and van de Walle (1997): West Africa, Central Africa, North Africa, South Africa, and East Africa. We construct an indicator variable for each region and then individually include each indicator variable and its interaction with ruggedness in equation (5). The estimates are reported in table 4. The results show that for West Africa and North Africa, there is a statistically different effect of ruggedness relative to the average for all of Africa. Within West Africa, the positive effect of ruggedness is significantly larger. This is consistent with the positive effect of ruggedness working through the slave trades and with West Africa being the region most severely affected by the slave trades. In North Africa, where slave capture was almost completely absent, there is no positive effect of ruggedness. ${ }^{20}$ The results also show that the other three regions lie between these two extremes. For these regions, the positive differential effect of ruggedness is not statistically different from that for Africa as a whole.

Our finding that, across regions within Africa, the magnitudes of the differential effects of the ruggedness align closely with the intensity of the slave trades provide suggestive evidence that the differential effect of ruggedness within Africa is intimately linked to the slave trades. In the following sections, we examine this directly and provide additional evidence that this is in fact the case.

\footnotetext{
${ }^{20}$ This is calculated by adding the coefficient of the North Africa interaction to the coefficient of the Africa interaction. This gives $0.406+-0.404=$ -0.002 .
} 
TABLE 4.-DifFERENTIAL EFFECTS OF RUGGEDNESS ACROSS REGIONS WITHIN AFRICA

\begin{tabular}{|c|c|c|c|c|c|}
\hline & \multicolumn{5}{|c|}{ Dependent Variable: Log Real GDP per Person, 2000} \\
\hline & (1) & (2) & (3) & (4) & (5) \\
\hline Ruggedness & $\begin{array}{l}-0.203 \\
(0.093)^{* *}\end{array}$ & $\begin{array}{l}-0.203 \\
(0.093)^{* *}\end{array}$ & $\begin{array}{l}-0.203 \\
(0.093)^{* *}\end{array}$ & $\begin{array}{l}-0.203 \\
(0.093)^{* *}\end{array}$ & $\begin{array}{l}-0.203 \\
(0.093)^{* *}\end{array}$ \\
\hline Ruggedness $\times I^{\text {Africa }}$ & $\begin{array}{l}0.312 \\
(0.159)^{* *}\end{array}$ & $\begin{array}{l}0.408 \\
(0.161)^{* *}\end{array}$ & $\begin{array}{l}0.409 \\
(0.147)^{* * *}\end{array}$ & $\begin{array}{l}0.406 \\
(0.147)^{* * *}\end{array}$ & $\begin{array}{l}0.448 \\
(0.179)^{* *}\end{array}$ \\
\hline$I^{\text {Africa }}$ & $\begin{array}{l}-1.735 \\
(0.291)^{* * *}\end{array}$ & $\begin{array}{l}-1.844 \\
(0.229)^{* * *}\end{array}$ & $\begin{array}{l}-2.008 \\
(0.230)^{* * *}\end{array}$ & $\begin{array}{l}-2.046 \\
(0.222)^{* * *}\end{array}$ & $\begin{array}{l}-2.054 \\
(0.232)^{* * *}\end{array}$ \\
\hline Ruggedness $\times I^{\text {West Africa }}$ & $\begin{array}{l}0.532 \\
(0.154)^{* * *}\end{array}$ & & & & \\
\hline$I^{\text {West Africa }}$ & $\begin{array}{l}-0.635 \\
(0.283)^{* *}\end{array}$ & & & & \\
\hline Ruggedness $\times I^{\text {East Africa }}$ & & $\begin{array}{c}0.162 \\
(0.274)\end{array}$ & & & \\
\hline$I^{\text {East Africa }}$ & & $\begin{array}{r}-0.760 \\
(0.532)\end{array}$ & & & \\
\hline Ruggedness $\times I^{\text {Central Africa }}$ & & & $\begin{array}{c}0.575 \\
(1.197)\end{array}$ & & \\
\hline$I^{\text {Central Africa }}$ & & & $\begin{array}{c}0.020 \\
(0.597)\end{array}$ & & \\
\hline Ruggedness $\times I^{\text {North Africa }}$ & & & & $\begin{array}{l}-0.404 \\
(0.131)^{* * *}\end{array}$ & \\
\hline$I^{\text {North Africa }}$ & & & & $\begin{array}{l}1.465 \\
(0.241)^{* * *}\end{array}$ & \\
\hline Ruggedness $\times I^{\text {South Africa }}$ & & & & & $\begin{array}{l}-0.200 \\
(0.195)\end{array}$ \\
\hline$I^{\text {South Africa }}$ & & & & & $\begin{array}{c}0.592 \\
(0.519)\end{array}$ \\
\hline Constant & $\begin{array}{l}9.223 \\
(0.144)^{* * *}\end{array}$ & $\begin{array}{l}9.223 \\
(0.144)^{* * *}\end{array}$ & $\begin{array}{l}9.223 \\
(0.144)^{* * *}\end{array}$ & $\begin{array}{l}9.223 \\
(0.144)^{* * *}\end{array}$ & $\begin{array}{l}9.223 \\
(0.144)^{* * *}\end{array}$ \\
\hline Observations & 170 & 170 & 170 & 170 & 170 \\
\hline$R^{2}$ & 0.367 & 0.368 & 0.359 & 0.375 & 0.363 \\
\hline
\end{tabular}

\section{Do Slave Exports Account for Africa's Differential Effect?}

We now examine whether the slave trades can account for the differential effect of ruggedness within Africa. Our first step is to check for direct evidence that ruggedness provided protection against slave raiding. We do this using data from Nunn (2008) on the number of slaves taken from each country between 1400 and 1900 during Africa's four slave trades. The figures are constructed by combining historical shipping records with slave inventories reporting slave ethnicities (see the data appendix and Nunn, 2008, for details). Because the variable is very skewed to the left and some countries have no slave exports, we take the natural logarithm of 1 plus the measure: $\ln (1+$ slave exports/area). Using these data, we estimate equation (8) from section III. Results are reported in columns 5 to 7 of table 5 .

Column 5 of table 5 reports the unconditional relationship between ruggedness and slave exports among the 49 African countries in our sample. The estimate shows a negative and statistically significant relationship between ruggedness and slave exports and that ruggedness alone explains almost $30 \%$ of the variation in slave exports. This confirms hypothesis 2 : $\beta_{12}<0$ in equation (8). In columns 6 and 7, we include additional variables to address several potential concerns regarding the relationship between ruggedness and slave exports. We first include our baseline set of control variables. Among the four controls, the fraction of fertile soil is the only covariate that is statistically significant. The positive coefficient likely reflects the fact that soil fertility was an important determinant of having a dense and sedentary initial population, which led to more slaves being captured. In column 7, we include additional controls for other factors that may be important determinants of slave exports. We control directly for log population density in 1400 . This is a particularly important characteristic, since it is possible that the reason fewer slaves were taken from countries with greater terrain ruggedness is that there were fewer people living in more rugged areas, and not just because rugged terrain provided protection. The variable has a positive and statistically significant coefficient. Since Nunn (2008) shows that slave exports are decreasing in the distance from each country to the closest final destination in each of the four slave trades, we also include the sailing distance from each country's coast to the closest final destination for the transatlantic and Indian Ocean slave trades and the overland distance to the closest final destination for the trans-Saharan and Red Sea slave trades (measured in thousands of kilometers). For the transatlantic and Indian Ocean slave trades, in addition to the voyage by ship, slaves captured inland would have to be 
TABLE 5.-THE IMPACT AND DETERMINANTS OF SLAVE EXPORTS

\begin{tabular}{|c|c|c|c|c|c|c|c|}
\hline & \multicolumn{4}{|c|}{$\begin{array}{c}\text { Dependent Variable: } \\
\text { Log Real GDP } \\
\text { per Person, } 2000\end{array}$} & \multicolumn{3}{|c|}{$\begin{array}{c}\text { Dependent Variable: } \\
\text { Slave Export } \\
\text { Intensity }\end{array}$} \\
\hline & (1) & (2) & (3) & (4) & (5) & (6) & (7) \\
\hline Slave export intensity & $\begin{array}{l}-0.203 \\
(0.037)^{* * *}\end{array}$ & $\begin{array}{l}-0.222 \\
(0.035)^{* * *}\end{array}$ & $\begin{array}{l}-0.206 \\
(0.036)^{* * *}\end{array}$ & $\begin{array}{l}-0.214 \\
(0.034)^{* * *}\end{array}$ & & & \\
\hline Ruggedness & $\begin{array}{l}-0.203 \\
(0.093)^{* *}\end{array}$ & $\begin{array}{l}-0.169 \\
(0.077)^{* *}\end{array}$ & $\begin{array}{l}-0.231 \\
(0.077)^{* * *}\end{array}$ & $\begin{array}{l}-0.220 \\
(0.066)^{* * *}\end{array}$ & $\begin{array}{l}-1.330 \\
(0.262)^{* * *}\end{array}$ & $\begin{array}{l}-1.326 \\
(0.274)^{* * *}\end{array}$ & $\begin{array}{l}-0.989 \\
(0.358)^{* * *}\end{array}$ \\
\hline Ruggedness $\times I^{\text {Africa }}$ & $\begin{array}{c}0.124 \\
(0.152)\end{array}$ & & $\begin{array}{c}0.047 \\
(0.143)\end{array}$ & & & & \\
\hline$I^{\text {Africa }}$ & $\begin{array}{l}-0.819 \\
(0.317)^{* * *}\end{array}$ & $\begin{array}{l}-0.591 \\
(0.222)^{* * *}\end{array}$ & $\begin{array}{l}-0.825 \\
(0.356)^{\text {** }}\end{array}$ & $\begin{array}{l}-0.728 \\
(0.354)^{* *}\end{array}$ & & & \\
\hline Diamonds & & & $\begin{array}{l}0.028 \\
(0.010)^{* * *}\end{array}$ & $\begin{array}{l}0.028 \\
(0.010)^{* * *}\end{array}$ & & $\begin{array}{r}-0.005 \\
(0.006)\end{array}$ & $\begin{array}{r}-0.001 \\
(0.005)\end{array}$ \\
\hline Diamonds $\times I^{\text {Africa }}$ & & & $\begin{array}{l}-0.027 \\
(0.010)^{* *}\end{array}$ & $\begin{array}{l}-0.027 \\
(0.010)^{* * *}\end{array}$ & & & \\
\hline$\%$ fertile soil & & & $\begin{array}{r}-0.002 \\
(0.003)\end{array}$ & $\begin{array}{r}-0.002 \\
(0.003)\end{array}$ & & $\begin{array}{l}0.042 \\
(0.015)^{* * *}\end{array}$ & $\begin{array}{c}0.031 \\
(0.019)\end{array}$ \\
\hline$\%$ fertile soil $\times I^{\text {Africa }}$ & & & $\begin{array}{c}0.000 \\
(0.006)\end{array}$ & $\begin{array}{c}0.001 \\
(0.006)\end{array}$ & & & \\
\hline$\%$ tropical climate & & & $\begin{array}{l}-0.009 \\
(0.002)^{* * *}\end{array}$ & $\begin{array}{l}-0.009 \\
(0.002)^{* * *}\end{array}$ & & $\begin{array}{c}0.013 \\
(0.009)\end{array}$ & $\begin{array}{c}0.003 \\
(0.010)\end{array}$ \\
\hline$\%$ tropical climate $\times I^{\text {Africa }}$ & & & $\begin{array}{l}0.009 \\
(0.003)^{* * *}\end{array}$ & $\begin{array}{l}0.008 \\
(0.003)^{* * *}\end{array}$ & & & \\
\hline Distance to coast & & & $\begin{array}{l}-1.039 \\
(0.194)^{* * *}\end{array}$ & $\begin{array}{l}-1.039 \\
(0.194)^{* * *}\end{array}$ & & $\begin{array}{c}0.154 \\
(1.174)\end{array}$ & $\begin{array}{r}-1.939 \\
(1.694)\end{array}$ \\
\hline Distance to coast $\times I^{\text {Africa }}$ & & & $\begin{array}{r}-0.162 \\
(0.321)\end{array}$ & $\begin{array}{c}-0.191 \\
(0.343)\end{array}$ & & & \\
\hline Log population density 1400 & & & & & & & $\begin{array}{c}0.326 \\
(0.179)^{*}\end{array}$ \\
\hline Dist. Saharan slave market & & & & & & & $\begin{array}{l}-1.670 \\
(0.914)^{*}\end{array}$ \\
\hline Dist. Atlantic slave market & & & & & & & $\begin{array}{l}-0.973 \\
(0.480)^{* *}\end{array}$ \\
\hline Dist. Red Sea slave market & & & & & & & $\begin{array}{c}-0.082 \\
(0.635)\end{array}$ \\
\hline Dist. Indian slave market & & & & & & & $\begin{array}{l}-0.925 \\
(0.486)^{*}\end{array}$ \\
\hline Constant & $\begin{array}{l}9.223 \\
(0.144)^{* * *}\end{array}$ & $\begin{array}{l}9.175 \\
(0.127)^{* * *}\end{array}$ & $\begin{array}{l}9.959 \\
(0.195)^{* * *}\end{array}$ & $\begin{array}{l}9.943 \\
(0.195)^{* * *}\end{array}$ & $\begin{array}{l}5.572 \\
(0.503)^{* * *}\end{array}$ & $\begin{array}{l}3.575 \\
(1.251)^{* * *}\end{array}$ & $\begin{array}{l}22.359 \\
(10.008)^{* *}\end{array}$ \\
\hline Observations & 170 & 170 & 170 & 170 & 49 & 49 & 49 \\
\hline$R^{2}$ & 0.418 & 0.415 & 0.586 & 0.585 & 0.289 & 0.448 & 0.587 \\
\hline
\end{tabular}

Coefficients are reported with robust standard errors in brackets. ${ }^{* * *},{ }^{* *}$, and ${ }^{*}$ indicate significance at the $1 \%, 5 \%$, and $10 \%$ levels.

brought to the coast. Our distance-to-coast variable accounts for this. ${ }^{21}$ The ruggedness coefficient remains negative and significant at the $1 \%$ level even after controlling for these additional factors.

Having established that rugged terrain deterred slave exports, we now turn to showing that slave exports are negatively related to current economic outcomes and that this fully accounts for the differential effect of ruggedness within Africa. In column 1 of table 5, we estimate equation (7) from section III. This is identical to equation (5) (for which we reported estimates in column 1 of table 1), except that slave exports are also included in the estimating equation. Column 3 reports the same estimation as column 1 except that we also

\footnotetext{
${ }^{21}$ It is possible that land sufficiently distant from the coast was not exposed to the slave trades and that therefore a measure that places greater emphasis on the amount of land below a threshold distance from the coast is a more precise determinant. If we use the percentage of a country's land area that is more than 100 kilometers from the coast instead of the distance to the nearest coast, the results are qualitatively identical.
}

include our baseline set of control variables from table 1 in the estimating equation. With or without the full set of controls, when slave exports are controlled for, the differential effect of ruggedness within Africa disappears. The estimated coefficient on ruggedness $\cdot I^{\text {Africa }}$ is close to 0 and is no longer statistically significant. This confirms hypothesis $4: \beta_{8}=0$ in equation (7). It provides support for the explanation that the differential effect of ruggedness arises because of the slave trades.

In columns 2 and 4, we reestimate the specifications of, respectively, columns 1 and 3, leaving out the interaction between ruggedness and the Africa indicator variable. The estimates confirm hypothesis 3, which states that current economic outcomes in Africa are worse in places more affected by the slave trades: $\beta_{10}<0$ in equation (7). We can also see in columns 2 and 4 that the common effect of ruggedness, once slave exports are accounted for, is negative and very close to the magnitudes from columns 1 and 6 of table 1 . This confirms hypothesis 5 , which states that $\beta_{7}$ in equation 
(7) provides a consistent estimate of the common effect of ruggedness on income for the world as a whole. ${ }^{22}$

The estimates from table 5 can be used to calculate an alternative estimate of the indirect historic effect of ruggedness on income. The coefficients for slave export intensity from columns 1 and 3 provide estimates of the effect of slave exports on income: $\beta \gamma$ from equation (6). The coefficients for ruggedness from columns 5 to 7 provide estimates of $\lambda$ from equation (1). Therefore, the product of the two coefficients provides an alternative estimate of the indirect historic effect of ruggedness $\beta \gamma \lambda$. Because this is a direct estimate of the effect of ruggedness that works through the slave trades, it is potentially more precise than our reduced-form estimate $-\beta_{2}$ from equation (5) - which is based solely on the differential effect of ruggedness within Africa.

Consider the estimates with our baseline set of control variables, reported in columns 4 and 6 of table 5. They give $\widehat{\beta \gamma}=-0.206$ and $\hat{\lambda}=-1.326$. Therefore, $\widehat{\beta \gamma} \hat{\lambda}=$ $-0.206 \times-1.326=0.273$. We can compare this estimate to our reduced-form estimate reported in column 6 of table 1, which is 0.321 . The indirect effect of ruggedness working through slave exports is almost identical to the reduced-form differential effect of ruggedness within Africa estimated in section IV. This provides reassuring confirmation that the reduced-form differential effect of ruggedness within Africa is in fact being driven by the historic effect of ruggedness working through Africa's slave trades.

\section{A. Economic Magnitude of the Effects}

To this point, we have been focusing on the statistical significance of our estimated coefficients, ignoring the magnitude of their effects. Using the estimates from table 5, we now undertake a number of counterfactual calculations to show that the economic magnitudes of the indirect historic impact of ruggedness, working through the slave trades, are substantial.

We first consider the estimated magnitude of the impact of the slave trades on income. For context, consider a hypothetical African country with the mean level of slave exports and mean log real GDP per person among African countries. According to the estimates from column 3 of table 5, if this country was instead completely untouched by the slave trades, then its per capita income would increase by $\$ 2,365$, from $\$ 1,784$ to $\$ 4,149.23$

We next consider the magnitude of the historic benefit of ruggedness, which occurs through reduced slave exports.

\footnotetext{
22 If we estimate equation (7) without controlling for slave exports, then we estimate a small negative coefficient for ruggedness that is not significantly different from 0 (coefficient -0.067 with standard error 0.082 ). This is as expected. The negative common effect of ruggedness is biased upward (toward 0), since the positive effect of ruggedness within Africa is not being taken into account.

${ }^{23}$ This is calculated from: $\ln y^{\prime}=\ln 1,784-0.206 \times(-4.09)$, where 4.09 is the mean slave export intensity measure among African countries, -0.206 is the estimated impact of slave exports on income (from column 3 of table 5), and $y^{\prime}$ denotes the counterfactual income, had the slave trades not occurred in the hypothetical country. Solving for $y^{\prime}$ gives $\$ 4,149$.
}

Consider the benefit of a 1 standard deviation increase in ruggedness from the average of 1.110 to 2.389 . According to the estimates from column 6 of table 5, this reduces slave exports by $1.326 \times 1.279=1.70$, which is a 0.54 standard deviation decline in slave export intensity. This in turn increases $\log$ real GDP per person by $\$ 747$, from the average $\$ 1,784$ to $\$ 2,531$, which is a 0.37 standard deviation increase in log income per person. ${ }^{24}$

These effects are substantial, particularly given that we are considering the historic impact of one very specific geographic characteristic, terrain ruggedness, working through one historic event, the slave trades.

\section{B. The Effect of Slave Exports on Income through Rule of Law}

We have so far estimated the indirect effect of ruggedness on income, $\beta \gamma \lambda$, in two ways: (a) estimating the reduced-form relationship between income and ruggedness from equation (4) to obtain the combined differential effect of ruggedness within Africa $\widehat{\beta \gamma \lambda}$ and (b) estimating separately the effect of ruggedness on slave exports from equation (1) to obtain $\hat{\lambda}$ and the effect of slave exports on income of equation (6) to obtain $\widehat{\beta \gamma}$. A third alternative is to estimate equations (1) to (3) separately to obtain $\hat{\lambda}, \hat{\beta}$, and $\hat{\gamma}$ independently. One problem with this third alternative is that it is difficult to obtain an appropriate measure for $q_{i}$, which summarizes the different aspects of the organization of societies that are negatively affected by the slave trades. As a partial step in this direction, we use the rule-of-law variable from the World Bank's Worldwide Governance Indicators database (Kaufmann, Kraay, \& Mastruzzi, 2008). Estimates of equations (1) and (2) using this variable are reported in table 6 .

The first two columns of the table report estimates of equation (1), which captures the effects of institutional quality, as proxied by the rule of law, on real per capita income in 2000 . In column 1, we control for the Africa indicator variable only, and in column 2 we also control for our standard set of control variables and their interactions with the Africa indicator variable. The estimates show a strong negative, and statistically significant, relationship between the rule of law and per capita income. This result confirms the findings from a number of previous studies that stress the importance of governance and domestic institutions for long-term economic development (Acemoglu et al., 2001).

Columns 3 to 5 of table 6 report estimates of equation (2), which models the relationship between slave exports and the quality of the organization of societies. The estimates of column 3 control for the Africa indicator variable only. We include the Africa indicator to ensure that our estimated effect of slave exports on institutional quality is not estimated from the difference between Africa and the rest of the world.

\footnotetext{
${ }^{24}$ This is calculated from: $\ln y^{\prime}=\ln 1,784-0.206 \times(-1.326 \times 1.279)$, where 1.279 is the standard deviation of ruggedness among African countries, -1.326 is the estimated impact of ruggedness on slave exports (from column 6 of table 5), and -0.206 is the estimated impact of slave exports on income (from column 3 of table 5). Solving for $y^{\prime}$ gives $\$ 2,531$.
} 
TABle 6.-The EFFECT OF SLAVE EXPORTS ON INCOME THROUGH RULE OF LAW

\begin{tabular}{|c|c|c|c|c|c|}
\hline & \multicolumn{2}{|c|}{$\begin{array}{c}\text { Dependent Variable: } \\
\text { Log Real GDP } \\
\text { per Person, } 2000\end{array}$} & \multicolumn{3}{|c|}{$\begin{array}{c}\text { Dependent Variable: } \\
\text { Rule of } \\
\text { Law }\end{array}$} \\
\hline & (1) & (2) & (3) & (4) & (5) \\
\hline Rule of law, 1996-2000 & $\begin{array}{l}0.871 \\
(0.044)^{* * *}\end{array}$ & $\begin{array}{l}0.813 \\
(0.059)^{* * *}\end{array}$ & & & \\
\hline Ruggedness & $\begin{array}{r}-0.034 \\
(0.041)\end{array}$ & $\begin{array}{r}-0.051 \\
(0.039)\end{array}$ & & $\begin{array}{l}-0.147 \\
(0.067)^{* *}\end{array}$ & $\begin{array}{l}-0.156 \\
(0.049)^{* * *}\end{array}$ \\
\hline$I^{\text {Africa }}$ & $\begin{array}{l}-0.699 \\
(0.131)^{* * *}\end{array}$ & $\begin{array}{r}-0.109 \\
(0.352)\end{array}$ & $\begin{array}{l}-0.509 \\
(0.188)^{* * *}\end{array}$ & $\begin{array}{l}-0.885 \\
(0.306)^{* * *}\end{array}$ & $\begin{array}{l}-0.935 \\
(0.344)^{* * *}\end{array}$ \\
\hline Slave export intensity & & & $\begin{array}{l}-0.086 \\
(0.031)^{* * *}\end{array}$ & $\begin{array}{l}-0.098 \\
(0.034)^{* * *}\end{array}$ & $\begin{array}{l}-0.100 \\
(0.033)^{* * *}\end{array}$ \\
\hline Diamonds & & $\begin{array}{c}0.009 \\
(0.014)\end{array}$ & & $\begin{array}{l}0.028 \\
(0.009)^{* * *}\end{array}$ & $\begin{array}{l}0.019 \\
(0.008)^{* *}\end{array}$ \\
\hline Diamonds $\times I^{\text {Africa }}$ & & $\begin{array}{r}-0.009 \\
(0.015)\end{array}$ & & $\begin{array}{l}-0.026 \\
(0.009)^{* * *}\end{array}$ & $\begin{array}{l}-0.017 \\
(0.008)^{* *}\end{array}$ \\
\hline$\%$ Fertile soil & & $\begin{array}{c}0.000 \\
(0.002)\end{array}$ & & $\begin{array}{r}-0.002 \\
(0.003)\end{array}$ & $\begin{array}{c}0.003 \\
(0.003)\end{array}$ \\
\hline$\%$ Fertile soil $\times I^{\text {Africa }}$ & & $\begin{array}{l}-0.015 \\
(0.006)^{* *}\end{array}$ & & $\begin{array}{l}0.011 \\
(0.005)^{* *}\end{array}$ & $\begin{array}{c}0.006 \\
(0.005)\end{array}$ \\
\hline$\%$ Tropical climate & & $\begin{array}{c}-0.002 \\
(0.001)\end{array}$ & & $\begin{array}{l}-0.010 \\
(0.002)^{* * *}\end{array}$ & $\begin{array}{l}-0.011 \\
(0.002)^{* * *}\end{array}$ \\
\hline$\%$ Tropical climate $\times I^{\text {Africa }}$ & & $\begin{array}{c}0.003 \\
(0.003)\end{array}$ & & $\begin{array}{c}0.004 \\
(0.003)\end{array}$ & $\begin{array}{l}0.006 \\
(0.003)^{* *}\end{array}$ \\
\hline Distance to coast & & $\begin{array}{r}-0.221 \\
(0.174)\end{array}$ & & $\begin{array}{l}-0.984 \\
(0.189)^{* * *}\end{array}$ & $\begin{array}{l}-0.427 \\
(0.162)^{* * *}\end{array}$ \\
\hline Distance to coast $\times I^{\text {Africa }}$ & & $\begin{array}{l}-0.576 \\
(0.347)^{*}\end{array}$ & & $\begin{array}{c}0.233 \\
(0.296)\end{array}$ & $\begin{array}{c}-0.340 \\
(0.270)\end{array}$ \\
\hline$I^{\text {French civil law }}$ & & & & & $\begin{array}{l}-0.528 \\
(0.157)^{* * *}\end{array}$ \\
\hline$I^{\text {French civil law }} \times I^{\text {Africa }}$ & & & & & $\begin{array}{l}0.463 \\
(0.230)^{* *}\end{array}$ \\
\hline$I^{\text {Socialist law }}$ & & & & & $\begin{array}{l}-1.183 \\
(0.192)^{* * *}\end{array}$ \\
\hline$I^{\text {German civil law }}$ & & & & & $\begin{array}{l}0.640 \\
(0.331)^{*}\end{array}$ \\
\hline$I^{\text {Scandinavian law }}$ & & & & & $\begin{array}{l}0.774 \\
(0.209)^{* * *}\end{array}$ \\
\hline Constant & $\begin{array}{l}8.783 \\
(0.076)^{* * *}\end{array}$ & $\begin{array}{l}8.922 \\
(0.159)^{* * *}\end{array}$ & $\begin{array}{l}0.218 \\
(0.087)^{* *}\end{array}$ & $\begin{array}{l}1.113 \\
(0.198)^{* * *}\end{array}$ & $\begin{array}{l}1.244 \\
(0.226)^{* * *}\end{array}$ \\
\hline Observations & 169 & 169 & 169 & 169 & 169 \\
\hline$R^{2}$ & 0.746 & 0.776 & 0.191 & 0.449 & 0.644 \\
\hline
\end{tabular}

Because slave exports are 0 for all countries outside Africa and because we always control for an Africa fixed effect, the estimated coefficient for slave exports is estimated from the relationship between slave exports and institutional quality within Africa only. In columns 4 and 5, we include additional control variables. We first include our baseline set of control variables and their interactions with the Africa indicator variable. Then, in column 5 , we also add our legal origin fixed effects and their interactions with the Africa indicator variable. ${ }^{25}$ The estimates provide strong support for the slave trade adversely affecting domestic institutions today.

\footnotetext{
${ }^{25}$ Because our regression includes an Africa indicator variable, a full set of legal origin indicator variables, and interactions between them, non-African British common law countries constitute the omitted baseline category. Therefore, the differential effect (relative to this baseline) of the other legal origins for non-African countries is given by the coefficients of the legal origin indicator variables, while the differential effect of the other legal origins for African countries is given by the interaction of the legal origin indicators with the Africa indicator variable. Because African countries are only of either British or French legal origin, and none are of socialist, German, or Scandinavian legal origin, indicator variables for these later
}

The coefficient for slave exports is negative and statistically significant.

Combining the estimated coefficients $\hat{\lambda}=-1.326$ from column 6 of table $5, \hat{\beta}=0.813$ from column 2 of table 6 , and $\hat{\gamma}=-0.065$ from column (4) of table 6 yields $\hat{\lambda} \times \hat{\beta} \times \hat{\gamma}=$ 0.070 . Like the reduced-form estimate from column 6 of table 1 , the indirect effect of ruggedness is found to be positive. However, the magnitude from the structural estimates is just under one-fourth of the magnitude implied by the reduced-form estimate. This occurs because our structural estimates implicitly assume that the only effect of slave exports on income is through the rule of law. Any effect of the slave trade on per capita income that does not occur through our measured rule of law will not be captured when we estimate $\beta$ and $\gamma$ individually. This is not true, however, for our estimate of the relationship between slave exports

three groups interacted with the Africa indicator variable are dropped from the regression. 
and income, $\widehat{\beta \gamma}=-0.206$. The relationship between slave exports and income implied by the individual estimates of $\beta$ and $\gamma$ is $\hat{\beta} \times \hat{\gamma}=0.813 \times-0.065=-0.053$. The difference between the two estimated magnitudes is consistent with the slave trade affecting income through channels other than the rule of law. Exploring such channels is the subject of ongoing research. For instance, the recent results of Nunn and Wantchekon (forthcoming), which show that the slave trades had a negative effect on levels of trust 100 years after the end of the trade, provide evidence that the slave trades likely affect current income levels through a variety of additional channels other than the rule of law. ${ }^{26}$

\section{Conclusions}

The study provides evidence showing that geography can have important effects on income through its interaction with historical events. By focusing on a dimension of geography, terrain ruggedness, which varies throughout the world and on a historical event, the slaves trades over the period 1400 to 1900 , which is geographically confined to Africa, we are able to estimate the indirect historic effect of ruggedness on income. For the world as a whole, we find a negative relationship between ruggedness on income. We also find that rugged terrain had an additional effect in Africa during the fifteenth to nineteenth centuries: it afforded protection to those being raided during Africa's slave trades. By allowing areas to escape from the detrimental effects that the slave trades had on subsequent economic development, ruggedness also creates long-run benefits in Africa through an indirect historic channel. We show that this differential effect of ruggedness is found in Africa only, it cannot be explained by Africa's unique geographic environment, and it is fully accounted for by Africa's slave trades. On the whole, the results provide one example of the importance of geography through historic channels.

${ }^{26}$ An additional channel through which the slave trades can negatively affect income today is ethnic conflict. Slaves were almost exclusively captured by other Africans (Koelle, 1854; Nunn \& Wantchekon, forthcoming). This triggered conflicts between neighboring ethnicities, which may still persist today (Azevedo, 1982; Inikori, 2000; Hubbell, 2001). Identifying this channel empirically is difficult because it is possible that the seeds of ethnic conflict were planted before the slave trades and we do not have data on ethnic conflict prior to the slave trades. However, we note that our results are robust to controlling for years of violent civil conflict, 1975-1999, using data from Fearon and Laitin (2003).

\section{REFERENCES}

Acemoglu, Daron, Simon Johnson, and James A. Robinson, "The Colonial Origins of Comparative Development: An Empirical Investigation," American Economic Review 91:5 (2001), 1369-1401.

"Reversal of Fortune: Geography and Institutions in the Making of the Modern World Income Distribution," Quarterly Journal of Economics 117:4 (2002), 1231-1294.

Allen, Bryant, R. Michael Bourke, and John Gibson, "Poor Rural Places in Papua New Guinea," Asia Pacific Viewpoint 46:2 (2005), 201-217.

Azevedo, Mario, "Power and Slavery in Central Africa: Chad (1890-1925)," Journal of Negro History 67:3 (1982), 198-211.

Bah, Thierno Mouctar, "The Impact of Wars on Housing in Pre-Colonial Black Africa," African Environment 76:3 (1976), 3-18.
Architecture Militaire Traditionalle et Poliorcétique dans le Soudan Occidental (Yaondé, Cameroon: Editions CLE, 1985)

"Slave-Raiding and Defensive Systems South of Lake Chad from the Sixteenth to the Nineteenth Century" (pp. 15-49), in Sylviane A. Diouf (Ed.), Fighting the Slave Trade: West African Strategies (Athens, OH: Ohio University Press, 2003).

Belsley, David A., Edwin Kuh, and Roy E. Welsch, Regression Diagnostics: Identifying Influential Data and Sources of Collinearity (Hoboken, NJ: Wiley, 1980).

Brasseur, Georges, Les Etablissements Humains au Mali (Dakar, Senegal: Mémoires de l'IFAN, 1968).

Bratton, Michael, and Nicolas van de Walle, "Political Regimes and Regime Transitions in Africa, 1910-1994," Inter-University Consortium for Political and Social Research data collection no. 6996 (1997).

Burchfield, Marcy, Henry G. Overman, Diego Puga, and Matthew A. Turner, "Causes of Sprawl: A Portrait from Space," Quarterly Journal of Economics 121:2 (2006), 587-633.

Center for International Earth Science Information Network, National Aggregates of Geospatial Data Collection: Population, Landscape, and Climate Estimates (PLACE) (New York: Center for International Earth Science Information Network, Columbia University, 2003).

Collier, Paul, and Anke Hoeffler, "Greed and Grievance in Civil War," Oxford Economic Papers 56:4 (2004), 563-595.

Cordell, Dennis D., "The Myth of Inevitability and Invincibility: Resistance to Slavers and the Slave Trade in Central Africa, 1850-1910" (pp. 31-49), in Sylviane A. Diouf (Ed.), Fighting the Slave Trade: West African Strategies (Athens, OH: Ohio University Press, 2003).

Dell, Melissa, "The Persistent Effects of Peru's Mining Mita," Econometrica 78 (2010), 1863-1903.

Diamond, Jared, Guns, Germs, and Steel (New York: Norton, 1997).

Engerman, Stanley L., and Kenneth L. Sokoloff, "Factor Endowments, Institutions, and Differential Paths of Growth among New World Economies: A View from Economic Historians of the United States" (pp. 260-304), in Stephen Harber (Ed.), How Latin America Fell Behind (Stanford: Stanford University Press, 1997).

"Factor Endowments, Inequality, and Paths of Development among New World Economies," NBER working paper no. 9259 (2002).

Fearon, James D., and David Laitin, "Ethnicity, Insurgency, and Civil War," American Political Science Review 97 (2003), 75-90.

Fischer, Günther, Harrij van Velthuizen, Mahendra Shah, and Freddy Nachtergaele, Global Agro-Ecological Assessment for Agriculture in the 21 st Century (Laxenburg, Austria: Food and Agriculture Organization of the United Nations and International Institute for Applied Systems Analysis, 2002).

Food and Agriculture Organization, Guidelines for Land-Use Planning (Rome: Food and Agriculture Organization of the United Nations, 1993).

ResourceSTAT (Rome: Food and Agriculture Organization of the United Nations, 2008).

Gallup, John Luke, and Jeffrey D. Sachs, "The Economic Burden of Malaria," American Journal of Tropical Medicine and Hygiene 64:1-2 (2001), 85-96.

Gerrard, A. J. W., "What Is a Mountain?" World Bank Development Research Group working paper (2000).

Gleave, M. B., and R. M. Prothero, "Population Density and 'Slave Raiding'-A Comment," Journal of African History 12:2 (1971), 319-324.

Hubbell, Andrew, "A View of the Slave Trade from the Margin: Souroudougou in the Late Nineteenth-Century Slave Trade of the Niger Bend," Journal of African History 42:1 (2001), 25-47.

Inikori, Joseph E., "Africa and the Trans-Atlantic Slave Trade" (pp. 389412), in Toyin Falola (Ed.), Africa, Vol. 1: African History before 1885 (Durham, NC: Carolina Academic Press, 2000).

Kamarck, Andrew M., The Tropics and Economic Development (Baltimore, MD: John Hopkins University Press, 1976).

Kaufmann, Daniel, Aart Kraay, and Massimo Mastruzzi, "Governance Matters VII: Aggregate and Individual Governance Indicators, 1996-2007," World Bank policy research working paper no. 4654 (2008).

Kiszewski, Anthony, Andrew Mellinger, Andrew Spielman, Pia Malaney, Sonia Ehrlich Sachs, and Jeffrey Sachs, "A Global Index of the Stability of Malaria Transmission," American Journal of Tropical Medicine and Hygiene 70 (2004), 486-498. 
Koelle, Sigismund Wilhelm, Polyglotta Africana; or A Comparative Vocabulary of Nearly Three Hundred Words and Phrases, in More Than One Hundred Distinct African Languages (London: Church Missionary House, 1854).

Kottek, Markus, Jÿrgen Grieser, Christoph Beck, Bruno Rudolf, and Franz Rubel, "World Map of the Köppen-Geiger Climate Classification Updated," Meteorologische Zeitschrift 15:3 (2006), 259-263.

Kusimba, Chapurukha M., "Archaeology of Slavery in East Africa," African Archaeological Review 21:2 (2004), 59-88.

La Porta, Rafael, Florencio Lopez-de-Silanes, and Andrei Shleifer, "The Economic Consequences of Legal Origins," Journal of Economic Literature 46:2 (2008), 285-332.

La Porta, Rafael, Florencio Lopez-de-Silanes, Andrei Shleifer, and Robert Vishny, "The Quality of Government," Journal of Law, Economics and Organization 15:1 (1999), 222-279.

Lovejoy, Paul E., Transformations in Slavery: A History of Slavery in Africa, 2nd ed. (Cambridge: Cambridge University Press, 2000).

Maddison, Angus, Contours of the World Economy, 1-2030 AD: Essays in Macroeconomic History (New York: Oxford University Press, 2007).

Marchesseau, G., "Quelques éléments d'ethnographie sur les Mofu du massif de Durum," Bulletin de la Société d'Etudes Camerounaises 10:1 (1945), 7-54.

McEvedy, Colin, and Richard Jones, Atlas of World Population History (New York: Penguin Books, 1978)

Mehlum, Halvor, Karl Moene, and Ragnar Torvik, "Institutions and the Resource Curse," Economic Journal 116:508 (2006), 1-20.

Mellinger, Andrew, Jeffrey D. Sachs, and John Gallup, "Climate, Coastal Proximity, and Development" (pp. 169-194), in Gordon L. Clark, Maryann P. Feldman, and Meric S. Gertler (Eds.), Oxford Handbook of Economic Geography (New York: Oxford University Press, 2000).

Nogales, Alberto, Rodrigo Archondo-Callao, and Anil Bhandari, Road Cost Knowledge System (Washington, DC: World Bank, 2002).

Northrup, David, Trade without Rulers: Pre-Colonial Economic Development in South-Eastern Nigeria (Oxford, UK: Clarendon Press, 1978).

Nunn, Nathan, “The Long Term Effects of Africa's Slave Trades," Quarterly Journal of Economics 123:1 (2008), 139-176.

Nunn, Nathan, and Leonard Wantchekon, "The Slave Trade and the Origins of Mistrust in Africa," American Economic Review (forthcoming).

Oak Ridge National Laboratory, LandScan Global Population Database 2000 (Oak Ridge, TN: Oak Ridge National Laboratory, 2001).

Olken, Ben, "Do Television and Radio Destroy Social Capital? Evidence from Indonesian Villages," American Economic Journal: Applied Economics 1:4 (2009), 1-33.

Podlewski, André Michel, "Etude démographique de trois ethnies païennes du Nord-Cameroun: Matakam, Kapsiki, Goudé," Recherches et Etudes Camerounaises 4 (1961), 1-70.

Ramcharan, Rodney, "Does Economic Diversification Lead to Financial Development? Evidence from Topography," International Monetary Fund working paper no. 06/35, (2006).

Rappaport, Jordan, and Jeffrey D. Sachs, "The United States as a Coastal Nation," Journal of Economic Growth 8:1 (2003), 5-46.

Rapaport, Eric, and Folke Snickars, "GIS-Based Road Location in Sweden: A Case Study to Minimize Environmental Damage, Building Costs and Travel Time" (pp. 135-153), in John Stillwell, Stan Geertman, and Stan Openshaw (Eds.), Geographical Information and Planning (New York: Springer, 1999).

Riley, Shawn J., Stephen D. DeGloria, and Robert Elliot, "A Terrain Ruggedness Index That Quantifies Topographic Heterogeneity," Intermountain Journal of Sciences 5: 1-4 (1999), 23-27.

Robinson, James A., Ragnar Torvik, and Thierry Verdier, "Political Foundations of the Resource Curse," Journal of Development Economics $79: 2$ (2006), 447-468.

Sachs, Jeffrey, “The Geography of Poverty and Wealth," Scientific American 284 (2001), 70-75.

Sachs, Jeffrey, and Pia Malaney, "The Economic and Social Burden of Malaria," Nature 415:6872 (2002), 680-685.

Sachs, Jeffrey D., and Andrew M. Warner, "The Curse of Natural Resources," European Economic Review 45:4-6 (2001), 827-838.

Sokoloff, Kenneth L., and Stanley L. Engerman, "History Lessons: Institutions, Factor Endowments, and Paths of Development in the New World," Journal of Economic Perspectives 14:3 (2000), 217-232.
Teorell, Jan, and Axel Hadenius, "Determinants of Democratization: Taking Stock of the Large-N Evidence" (pp. 69-95), in Dirk Berg-Schlosser (Ed.), Democratization: The State of the Art (Opladen: Barbara Budrich Publishers, 2007).

United Nations, United Nations Common Database (New York: United Nations Statistics Division, 2007).

U.S. Bureau of Mines, Minerals Yearbook (Washington, DC: U.S. Government Printing Office, 1960-1996).

U.S. Geological Survey, GTOPO30 (Sioux Falls, SD: U.S. Geological Survey Center for Earth Resources Observation and Science, 1996). Minerals Yearbook (Washington, DC: U.S. Government Printing Office, 1997-2007).

U.S. National Imagery and Mapping Agency, Vector Map Level O/Digital Chart of the World, 5th ed. (Fairfax, VA: U.S. National Imagery and Mapping Agency, 2000).

World Bank, World Development Indicators (Washington, DC: World Bank, 2006).

\section{DATA APPENDIX}

\section{Data Availability}

All the data necessary to reproduce the results of this paper are available from http://diegopuga.org/data/rugged/.

\section{Country Boundaries}

We assign geographic features to countries using digital boundary data based on the fifth edition of the Digital Chart of the World (U.S. National Imagery and Mapping Agency, 2000), which we have updated to reflect country boundaries in 2000 using information from the International Organization for Standardization ISO 3166 Maintenance Agency and other sources. We exclude areas covered by inland water area features contained in the same edition of the Digital Chart of the World. When calculating the percentage of each country's land surface area with certain characteristics or the average value of a variable for a country, we perform all calculations on a 30 arc-second geographic grid, correcting for the fact that the actual land area covered by a 30 arc-second cell varies with latitude.

\section{Land Area}

The land area data are from the Food and Agriculture Organization (2008), except for Macau and Hong Kong where they are taken from the Encyclopedia Britannica.

\section{Income per Person}

We measure average country-level income by the natural logarithm of real GDP per person in 2000. The data are from the World Bank World Development Indicators (2006). Units are 2006 international dollars, with purchasing power parity conversions performed using the Elteto-KovesSzulc method.

To check the robustness of our results to the use of income data from other time periods and from an alternative source, in the text we refer to results using the natural logarithm of real GDP per person in 1950 and in 2000, and its annual average from 1950 to 2000, with data from Angus Maddison (Maddison, 2007, updated October 2008). Units are 1990 international dollars, with purchasing power parity conversions performed using the Geary-Khamis method.

\section{Gem-Quality Diamond Extraction}

Data on carats of gem-quality diamond extracted by each country between 1958 and 2000 are obtained from the 1959 to 2004 editions of the Mineral Yearbook, published first by the U.S. Bureau of Mines (19601996) and then by the US Geological Survey (1997-2007). We use the most recent data for each country-year in volume 1 (Metals and Minerals), completed with data from volume 3 (Area Reports: International) of the 1997-2000 editions. For countries that have split or changed boundaries, we assign diamond extraction on the basis of mine location with respect to current boundaries. The variable is then normalized by land area to obtain carats of gem-quality diamond per square kilometer. 


\section{Percentage of Each Country with Fertile Soil}

On the basis of the FAO/UNESCO Digital Soil Map of the World and linked soil association composition table and climatic data compiled by the Climate Research Unit of the University of East Anglia, Fischer et al. (2002) identify whether each cell on a 5-minute grid covering almost the entire land area of the earth is subject to various constraints for growing rainfed crops. Based on plates 20 (soil moisture storage capacity constraints), 21 (soil depth constraints), 22 (soil fertility constraints), 23 (soil drainage constraints), 24 (soil texture constraints), and 25 (soil chemical constraints) in Fischer et al. (2002) and the country boundaries described above, we calculate the percentage of the land surface area of each country that has fertile soil (defined as soil that is not subject to severe constraints for growing rain-fed crops in terms of either soil fertility, depth, chemical and drainage properties, or moisture storage capacity). Cape Verde, French Polynesia, Mauritius, and Seychelles are not covered by the Fischer et al. (2002) data, so for these countries, we use the percentage of their land surface area that is classified by the Food and Agriculture Organization (2008) as arable land or permanent crop land.

\section{Percentage of Each Country with Tropical Climate}

Using detailed temperature and precipitation data from the Climatic Research Unit of the University of East Anglia and the Global Precipitation Climatology Centre of the German Weather Service, Kottek et al. (2006) classify each cell on a 30 arc-minute grid covering the entire land area of the earth into one of 31 climates in the widely used Köppen-Geiger climate classification. Based on these data and the country boundaries described above, we calculate the percentage of the land surface area of each country that has any of the four Köppen-Geiger tropical climates.

\section{Average Distance to the Nearest Ice-Free Coast}

To calculate the average distance to the closest ice-free coast in each country, we first compute the distance to the nearest ice-free coast for every point in the country in equirectangular projection with standard parallels at 30 degrees, on the basis of sea and sea ice area features contained in the fifth edition of the Digital Chart of the World (U.S. National Imagery and Mapping Agency, 2000) and the country boundaries described above. We then average this distance across all land in each country not covered by inland water features. Units are thousands of kilometers.

\section{European Colonial Origin Indicators}

European colonial origin indicators are based on Teorell and Hadenius (2007). They distinguish British, French, Portuguese, Spanish, and other European (Dutch, Belgian, and Italian) colonial origin for countries colonized since 1700 . For countries under several colonial powers, the last one is counted provided that it lasted for ten years or longer. Since Teorell and Hadenius exclude the British settler colonies (the United States, Canada, Australia, Israel, and New Zealand), we code these as having a British colonial origin. We complete their data using the same rule to determine the European colonial origin of French Polynesia (French), Hong Kong (British), Macau (Portuguese), New Caledonia (French), Nauru (British), Philippines (Spanish), Puerto Rico (Spanish), and Papua New Guinea (British).

\section{Legal Origin Indicators}

Legal origin indicators (common law, French civil law, German civil law, Scandinavian law, and Socialist law) are from La Porta et al. (1999).
Some of our regressions include French Polynesia, absent from their data, which we have coded as French civil law.

\section{African Region Indicators}

Region indicators for sub-Saharan Africa (East Africa, Central Africa, West Africa, and South Africa) are from Bratton and van de Walle (1997). We assign African countries North of the Saharan desert, which were not classified by Bratton and van de Walle, to the region of North Africa.

\section{Slave Exports}

Estimates of the number of slaves exported between 1400 and 1900 in Africa's four slave trades are from Nunn (2008). The data are constructed by combining shipping data with data from various historic documents reporting the ethnicities of slaves shipped from Africa. Combining the two sources, Nunn is able to construct an estimate of the number of slaves shipped from each country in Africa between 1400 and 1900 during Africa's four slave trades. We normalize the export figures by a country's land surface area, computed as explained above. Because some country's have no slave exports, we take the natural logarithm of 1 plus the number of slaves exported per thousand square kilometers. See Nunn (2008) for more information on the nature of the data, including why it is appropriate to use the natural logarithm of slave exports.

\section{Quality of Governance}

To measure the quality of governance in each country, we use the composite variable rule of law from version VII of the World Bank's Worldwide Governance Indicators database (Kaufmann et al., 2008). It consists of "perceptions of the extent to which agents have confidence in and abide by the rules of society, and in particular the quality of contract enforcement, property rights, the police, and the courts, as well as the likelihood of crime and violence" (Kaufmann et al., 2008, p. 7).

\section{Distance to Export Markets}

Four variables measuring the distance from each country to the closest final destination slave market in each of Africa's four slave trades are taken from Nunn (2008). For the transatlantic and Indian Ocean slave trades, the measure is the sailing distance from the point on the coast that is closest to the country's centroid to the closest final export destination for slave trade. For the trans-Saharan and Red Sea slave trades, the measure is the great circle overland distance from the country's centroid to the closest final export destination for that slave trade. Units are thousands of kilometers.

\section{Population Density in 1400}

The data are constructed using historic population estimates from McEvedy and Jones (1978). For countries grouped with others in McEvedy and Jones, we allocate population to countries in the group according to the distribution of population in 1950, obtained from United Nations (2007). We normalize total population in 1400 by the land area of each country, calculated as described above. Because the variable is extremely skewed to the left and because the territory covered by some countries today had 0 population density in 1400, we take the natural logarithm of 1 plus population density (measured in people per square kilometer). 